Florida International University FIU Digital Commons

\title{
Examining Movement and Habitat Selection of Everglades Fishes in Response to Seasonal Water levels
}

GregoryJ. Hill

Florida International University, ghillo07@fiu.edu

DOI: $10.25148 /$ etd.FIDC001761

Follow this and additional works at: https:// digitalcommons.fiu.edu/etd

Part of the Animal Studies Commons, Behavior and Ethology Commons, Environmental Studies Commons, Integrative Biology Commons, Other Animal Sciences Commons, Other Ecology and Evolutionary Biology Commons, Terrestrial and Aquatic Ecology Commons, and the Zoology Commons

\section{Recommended Citation}

Hill, Gregory J., "Examining Movement and Habitat Selection of Everglades Fishes in Response to Seasonal Water levels" (2017). FIU Electronic Theses and Dissertations. 3209.

https://digitalcommons.fiu.edu/etd/3209 


\title{
FLORIDA INTERNATIONAL UNIVERSITY
}

Miami, Florida

\section{EXAMINING MOVEMENT AND HABITAT SELECTION OF EVERGLADES FISHES IN RESPONSE TO SEASONAL WATER LEVELS}

\author{
A thesis submitted in partial fulfillment of the \\ requirements for the degree of \\ MASTER OF SCIENCE \\ in \\ ENVIRONMENTAL STUDIES \\ by \\ Gregory Hill
}


To: Dean Michael R. Heithaus

College of Arts, Sciences, and Education

This thesis, written by Gregory Hill, and entitled Examining Movement and Habitat Selection of Everglades Fishes in Response to Seasonal Water Levels, having been approved in respect to style and intellectual content, is referred to you for judgement.

We have read this thesis and recommend that it be approved.

Kevin Boswell

Rene Price

Mark Cook

Jennifer Rehage, Major Professor

Date of Defense: March 10, 2017

The thesis of Gregory Hill is approved.

Dean Michael R. Heithaus

College of Arts, Sciences, and Education

Andrés G. Gil

Vice President for Research and Economic Development and Dean of the University Graduate School

Florida International University, 2017 


\title{
ABSTRACT OF THE THESIS
}

\section{EXAMINING MOVEMENT AND HABITAT SELECTION OF EVERGLADES FISHES IN RESPONSE TO SEASONAL WATER LEVELS}

\author{
by
}

\author{
Gregory J. Hill
}

Florida International University, 2017

\author{
Miami, Florida
}

\section{Professor Jennifer Rehage, Major Professor}

Fish distribution patterns and seasonal habitat use play a key role in the food web dynamics of aquatic ecosystems, including the Florida Everglades. In this study I examined the fine scale habitat shifts and movements of spotted sunfish, Lepomis punctatus across varying seasons and hydrologic conditions using in-situ field enclosures and Passive Integrated Transponder (PIT) systems. Data on fish use of three dominant Everglades marsh habitats and activity level were recorded continuously from January to August, 2015. Fish were more active and had the highest use of higher elevation habitats when water levels rose during an experimental reversal in mid-April. Fish activity was higher at increasing water levels relative to decreasing. Fish activity also varied with the rate of change, with the highest activity occurring during rapid increases in depth. Findings from this study provide insight on how fish response to changing water levels may affect foraging for wading birds, a key performance measure for Everglades restoration. 


\section{TABLE OF CONTENTS}

CHAPTER

PAGE

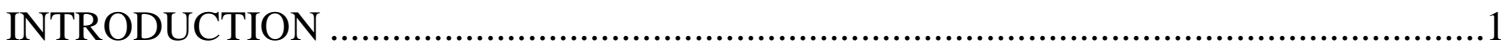

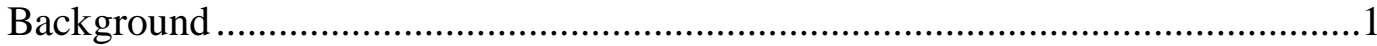

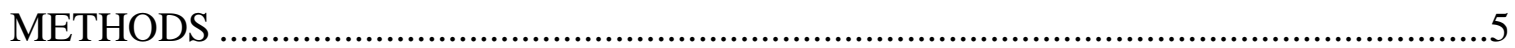

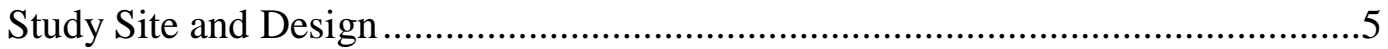

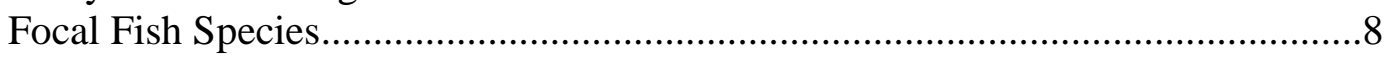

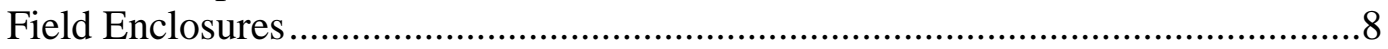

PIT tags \& Passive Antenna Systems .................................................................

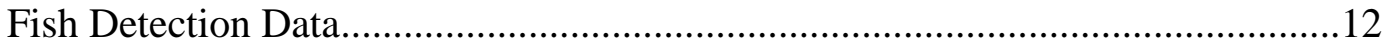

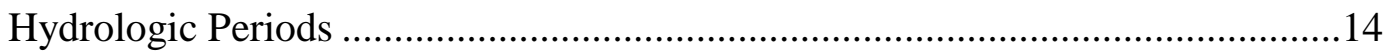

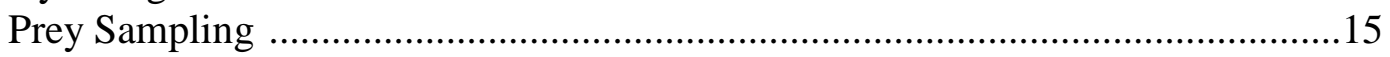

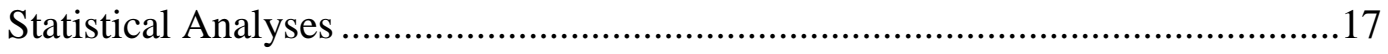

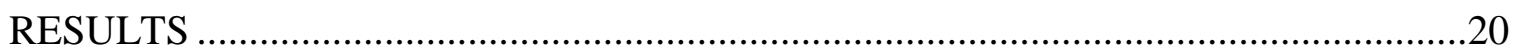

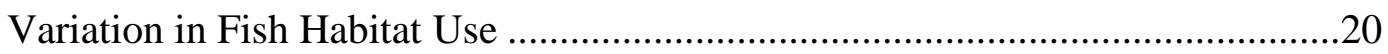

Fish Activity as a Function of Hydrologic Period and Direction ...........................22

Fish Activity in Response to Variation in rate.....................................................24

Invertebrate Abundance Relative to Sampling Period \& Habitat ...........................25

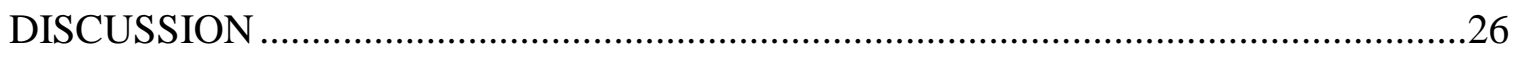

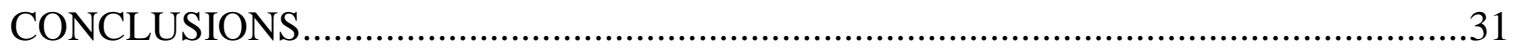

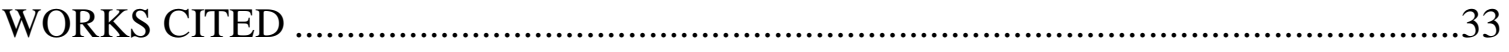




\section{LIST OF FIGURES}

FIGURE

PAGE

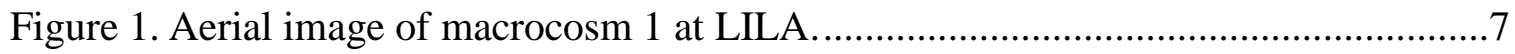

Figure 2. Profile of the 3 habitats contained in the 6 study enclosures. ..........................

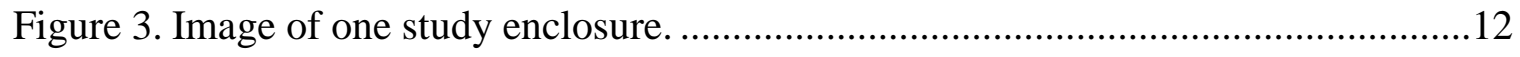

Figure 4. Water levels for the 2015 data run across the 3 habitats. ..............................16

Figure 5. Examples of continuous antenna detections for 2 spotted sunfish ..................17

Figure 6. Frequency of recession rates across 3 hydrostations ...................................19

Figure 7. Habitat use by period of interest across the 3 habitats ..................................21

Figure 8. Daily proportions of antenna detections for the 3 habitats (ridge, slough and alligator hole) averaged across all fish.......................................................22

Figure 9. Activity level of spotted sunfish by direction $\&$ hydrologic period ..................23

Figure 10 Activity level of spotted sunfish in response to the interaction of season and direction of depth change ....................................................................23

Figure 11 Activity level as a function of daily rate of change in water depth

Figure 12. Invertebrate abundance across sampling period and habitat. .25 


\section{ABBREVIATIONS AND ACRONYMS}

AdjAct

LILA

LOX

PIT

RFID
Adjusted Activity

Loxahatchee Impoundment Landscape Assessment

Arthur R. Marshall Loxahatchee National Wildlife

Refuge

Passive Integrated Transponder

Radio Frequency identification 


\section{INTRODUCTION}

\section{Background}

The decision to move is one of the major ways in which animals respond to changing environmental conditions and thus a critically important area of ecological research (Kays et al. 2015, Rubenstein \& Hobson 2004). The way in which animals move across different ecoscapes affects individual fitness, species interactions, biotic linkages, trophic dynamics, nutrient fluxes and conservation efforts key to maintaining the ecological integrity of ecosystems (Doughty et al. 2016, Roman, et al. 2014). In particular, movement patterns are highly responsive to both spatial and temporal variation in abiotic conditions (Hussey et al., 2015 Nathan et al. 2008). Among others, changes in thermal, climatic and hydrological regimes can be strong drivers of animal movement patterns at multiple temporal scales. For instance, research has shown that at the daily scale, snakes shift nocturnal habitat use to more thermally suitable rock structures (Webb et al. 2004), and that the seasonal movement paths of elephants change relative to rainfall patterns (Birkett et al. 2012).

In aquatic environments, changes in freshwater inflows and associated depth from seasonal rainfall, snowmelt, tidal currents, or dam releases often drive shifts in animal movement and habitat selection (Bunn \& Arthington 2002, Gasith et al 1999, Jackson et al. 2001, Mcfarland 2015, Zeman 2015,). A relatively large body of research shows that

freshwater fishes respond rapidly to such changes (Albanese et al. 2004, Davey \& Kelly 2007, Herbert \& Gelwick 2003). However the majority of these studies are based in lotic environments with an emphasis on flow pulse and temperature. Such factors are known to significantly affect fish life histories, such as the timing of spawning and recruitment 
success (Balcombe \& Arthington 2009, Dudgeon 2000, Jeffres et al. 2006), seasonal and daily foraging behavior (Mcfarland 2015, Harding Gradil 2015, Nielsen \& Lisle 1994), shifts in habitat preference (Roy et al. 2013, Roberts et al. 2016), and species assemblages (Rodger 2015). For example, fish use of floodplain and off-channel habitats is know to track water level flucutations in Australian rivers (Lyon et al. 2010) while the spawning cycle of fish in Russia's Volga River have been documented to coincide with flooding events (Gorski et al. 2010).

In lentic environments such as wetlands and floodplains, seasonal fluctuations in stage have a large influence on faunal distribution patterns by expanding and restricting movement corridors and the overall extent of habitat available (Hohausová et al. 2010, Gibbons 2003). The timing and magnitude of these stage fluctuations has been shown to be important to the reproductive and developmental cycles of many fish species (Balcombe \& Arthington 2009, Garcia et al. 2012, Zeug \& Winemiller, 2007). However, few studies have addressed how fish respond behaviorally to variation in depth in lentic systems (Johnson et al. 2006). In other words, to what extent and how do fish respond to changes in water levels by moving and altering habitat use patterns? Part of the knowledge gap in wetland fish movements stems from the difficulty and limitations involved with accessing and tracking fish in such expansive and dynamic environments. However, recent advances in technology (i.e., Passive Integrated Transponder (PIT) systems and telemetry) have mitigated this problem by providing novel approaches to studying movements of wetland species with high spatiotemporal resolution (e.g. Connolly 2010, Gibbons \& Andrews 2004, Rehage et al. 2014). 
In the Everglades, seasonal movement and distributional patterns of fishes play a vital role in food web dynamics and have large implications for Florida's multi-billion dollar fishing industry as well as the health of wading bird colonies- key performance measures of Everglades restoration (Fedler 2009, Frederick et al. 2009). There is, however, a lack of knowledge on exactly how seasonal changes in water levels influence fish behavior and movement patterns across the Everglades landscape. Additionally, how these changes influence prey abundances and thus the foraging behavior of fish and wading bird communities is also understudied. For instance, ridges, sloughs and alligator holes represent the dominant habitat gradient across marshes in the freshwater Everglades (McVoy et al. 2011), yet how fishes differentially use them in relation to varying water levels across seasons remains is poorly understood.

Previous studies have shown that fish move into deeper habitats (e.g. alligator holes, canals, costal creeks) as the dry season progresses (Kobza et al. 2004, Rehage \& Trexler 2006, Parkos et al. 2011, Rehage et al. 2013, Boucek \& Rehage 2013). These dry season concentrations provide an important seasonally-subsidized forage base for predatory gamefish such as Florida largemouth bass and common snook (Rehage \& Boucek 2013, Boucek et al. 2016). Fish can also become trapped and concentrated in lower elevation habitats (shallow sloughs) throughout the Everglades marsh landscape (Magoulick \& Kobza 2003, Parkos et al. 2011), providing high quality foraging patches for wading birds (Gawlik et al. 2008, Gawlik 2002, Kushlan et al. 1975, Crozier \& Gawlik 2003). The formation of these prey concentrations, however, are subject to the effects of water management as well as climate variation. For example, disruption of seasonal trends can alter the formation of prey concentrations and are of great concern to 
management and restoration efforts. Reversals, or sudden increases in water levels that reflood habitats during a typical dry down period, are on example of such a disruption (Beerens et al. 2011, Herring et al. 2010).

In this study, I asked how do changes in water levels affect the movement and distribution of fishes in Everglades marshes? In particular, I aimed to better understand the behavioral response of fish to: 1) increasing vs decreasing water levels, 2) Seasonal vs. unseasonal water changes (i.e., reversals), and 3) varying rates of changes in water levels. Additionally, I asked if the response of fish to changing water levels could be affected by changes in invertebrate abundances across periods of varying water conditions across Everglades habitats.

I hypothesized that fish would be more active and increase use of shallower habitats during increasing water levels and be less active with more use of deeper habitats as water levels recede. Second, I expected that fish movement and use of shallower habitats will be higher during unseasonal disturbance events (i.e. reversals) than during natural/seasonal changes in water level. Third, I expected that fish movement would increase with increasing rates of change in water level. High rates of change in water level may either leave fish stranded during recession or rapidly provide new habitat during reflooding. Therefore I expected fish to respond strongly to high rates. Lastly, I expected increases in fish movement and shallow habitat use to be associated with increased prey availability. Newly flooded habitats may be expected to be highly profitable with prey, motivating high movement rates and emigration as soon as these reflood. To address these questions, I examined fine-scale movement and habitat 
selection patterns of Everglades fishes using a combination of passive detection systems and enclosure techniques in experimental marsh habitats.

\section{METHODS}

\section{Study Site and Design}

I tracked the distribution of Everglades fish across varying water levels at the Loxahatchee Impoundment Landscape Assessment (LILA) facility, located in the Arthur R. Marshall Loxahatchee National Wildlife Refuge (LOX), West Palm Beach, Florida (FIGURE 1). LILA consists of four large (200m x 400m) macrocosms which contain the major representative habitats of the Everglades freshwater marsh in addition to a controlled water delivery system. The macrocosms thus provide an empirical setting where process and mechanistic questions about Everglades ecological patterns and restoration effects can be tested in accessible, controlled, and replicated Everglades marsh environments (Rehage et al. 2014)

For the purposes of my study, LILA allowed me to manipulate water levels and directly quantify their effects on fish distribution and movement across habitats. In particular, LILA allowed me to simulate seasonal conditions (water recession and rewetting conditions), as well as create unseasonal hydrological conditions via an induced mid-dry season sudden rewetting event or reversal. Reversals are considered abnormally large re-flooding events that occur unseasonably, rapidly increase water levels and the amount of habitats inundated, and are known to negatively impact wading bird foraging by allowing fish to disperse out of previous concentrations (Beerens et al. 2011, Herring et al. 2010, Rehage et al. 2014), although their exact effects on fish behavior have not been previously quantified. 
I used Passive Integrated Transponder (PIT) systems to continuously track the movements of individually-identified fish within in-situ enclosures constructed at LILA. The combination of PIT systems with in situ field enclosures has only been attempted by a couple previous studies (Greenberg \& Giller 2000, Greenberg et al. 2001), but can provided a novel and powerful experimental venue for the study of fine-grained movement and habitat selection behaviors under natural conditions (Rehage et al. 2014). 

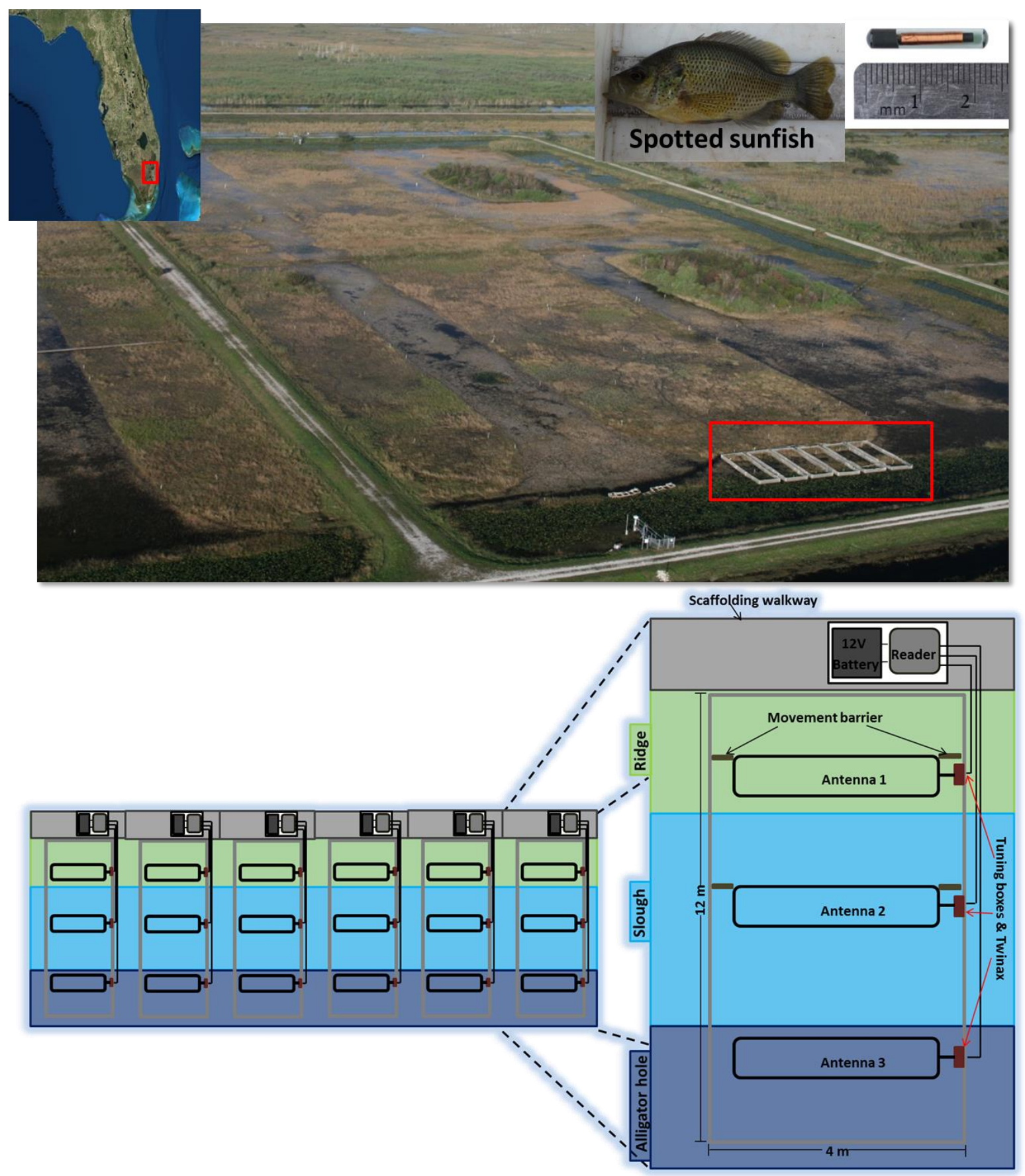

FIGURE 1. Aerial image of macroscosm 1 at LILA. Shows location of the 6 study enclosures. Top left map show location of LILA in the northern Everglades of Florida, bottom schematic shows set up of 6 enclosures, enclosure dimensions and setup of 3 antennas used for continous fish detection across ridge, slough and alligator hole habitats. Images on top right show focal fish species, native spotted sunfish (Lepomis punctatus), and a PIT tag used to uniquely identify internally tagged fish. 


\section{Focal Fish Species}

The focal species for this study was the spotted sunfish, Lepomis punctatus, a widespread centrarchid throughout the Everglades (Rehage \& Trexler 2006, Parkos et al. 2011, FIGURE 1). Centrarchids (sunfishes) are a dominant mesoconsumers in the freshwater Everglades (Rehage \& Trexler 2006, Chick et al. 2004, Parkos et al. 2011, Boucek \& Rehage 2013). Recent stomach content data shows that spotted sunfish are a dominant component of the diet of wood storks (Gawlik et al. unpublished data) and of economically valuable sportfish (Boucek \& Rehage 2013). Spotted sunfish, like other centrarchids, are also known to move and concentrate in dry season refuges such as alligator holes and coastal creeks (Parkos et al. 2011, Boucek \& Rehage 2013). Thus their distribution across Everglades habitats is expected to be strongly influenced by seasonal variation in water levels.

\section{Field Enclosures}

I used 6 large replicate enclosures $(12 \times 4 \mathrm{~m})$ located in macrocosm 1 of LILA (FIGURE 1). This size is an order of magnitude larger than typical enclosures used in aquatic empirical studies (4-6 m²; Flecker 1996, Greenberg \& Giller 2000, Winemiller et al. 2006, Power et al. 2008), yet small enough to allow for replication. Enclosures consisted of a steel frame with $1.3-\mathrm{cm}$ nylon mesh buried into sediment in order to selectively retain focal fish but allowed for the flow of water, nutrients, periphyton and prey (e.g., mosquitofish and grass shrimp) providing a self-sustaining system (FIGURE 2 \& 3).

Each enclosure contained the 3 key marsh habitats along a depth gradient in continuous $3 \mathrm{~m}, 6 \mathrm{~m}$, and $3 \mathrm{~m}$ swaths approximately matching field habitat availability 
(McVoy et al. 2011): 25\% shallow ridge (0-30 cm depth), 50\% mid-water slough (0-60 $\mathrm{cm}$ depth), and 25\% deep alligator-hole (70-120 $\mathrm{cm}$ depth, FIGURES 1-4). The 3 habitats experienced varying depths and extents of flooding as a function of controlled water levels (FIGURES 1-3). Mimicking conditions in the natural system, ridges and sloughs dry yearly at LILA, with ridges experiencing shallower depths and longer drying relative to sloughs (FIGURE 4). The alligator hole habitat is deep and retains water year round (Palmer \& Mazzotti 2004, Brandt et al. 2010). In our study, alligator holes are representative of other both natural and artificial deep water habitats (e.g., canals, solution holes, coastal creeks, retention ponds and the center of sloughs) that act as dry down refugia (Parkos et al. 2011,).

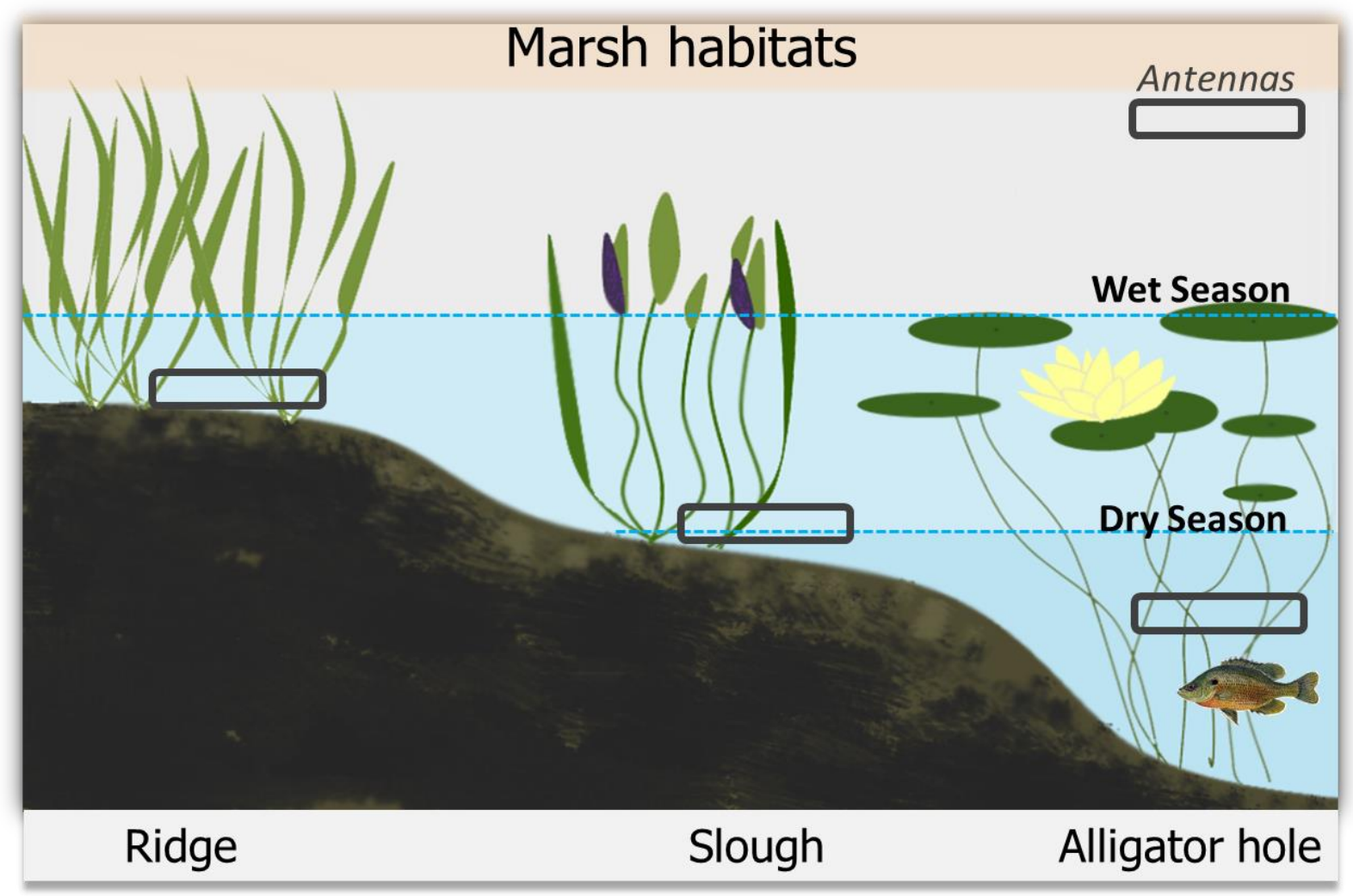

FIGURE 2. Profile of the 3 habitats contained in the 6 study enclosures. Shows the depth gradient across the wet and dry seasons and the approximate placement of antennas used for continuous fish detection. 


\section{PIT Tags \& Passive Antenna System}

PIT tags consist of an electronic microchip encased in biocompatible glass ( $23 \times 2$ $\mathrm{mm}$ diameter, $0.6 \mathrm{~g}$ ) that once inserted into the peritoneal cavity of fish serve as a permanent and unique identifier requiring no power source until activated by an antenna's electromagnetic field (FIGURE 1-2). PIT tags also have minimal influence on tagged organisms as long as the tags represent a small proportion of body weight $(<2 \%$; Skov et al. 2005, Adams et al. 2006). My PIT system consisted of 3 antennas (per enclosure) to continuously record the distribution of fish across ridge, slough and alligator hole habitats (FIGURES 1-3). The system was powered by deep cycle $12 \mathrm{~V}$ batteries and included tuning boxes to adjust antenna detection ranges and readers (halfduplex system, Oregon RFID®) to allocate power sequentially to antennas and store tag detections (FIGURE 1).

Antennas consisted of 3 loops of $12 \mathrm{AWG}$ stranded copper wire strung through corrugated plastic, spaced 1/4" apart, fitted around a 3 x $0.9 \mathrm{~m}$ PVC frame and set up horizontally (flat-bed design; Greenberg \& Giller 2000, FIGURE 1-3). I field tested and fine-tuned detectability with a dummy tag to ensure a continuous $60-75 \mathrm{~cm}$ read ranges over the perimeter of all antennas, comparable to those of previous work (Greenberg \& Giller 2000, Meynecke et al. 2008). In order for the PIT system to inform habitat use by spotted sunfish, antennas were placed at the edge of ridge and alligator hole, such that a detection by those antenna would denote entry and presence into two edge habitats. For the middle slough habitat, the antenna was setup on the center of the habitat (FIGURES 1-3). Because of depth variation and antenna dimensions, I placed antennas on the 
substrate in the ridge and slough and midwater column in alligator hole with a plastic barrier secured in the gap between the edge of the antenna and side of the enclosure. Placing the antennas in this manner allowed the read ranges to cover the entire water column vertically from substrate to surface, maximized the detection probability for fish moving through a given habitat and minimized electrical interference issues (Connolly, 2010).

When PIT-tagged fish crossed the electromagnetic field of an antenna at any depth, the unique code of the tag was read and stored in the data logger along with a date/time stamp. Thus, antenna detections accurately reflected movement of fish across the 3 habitats (Rehage et al. 2014, FIGURE 5). For instance, a fish using the ridge and moving to the alligator-hole habitat would first be detected by the ridge antenna, then the slough antenna, and lastly the alligator hole antenna (FIGURES 1-3) which allowed for measures of directional movement, and an account of time spent in each habitat by tagged fish (Greenberg \& Giller 2000, Rehage et al. 2014). 


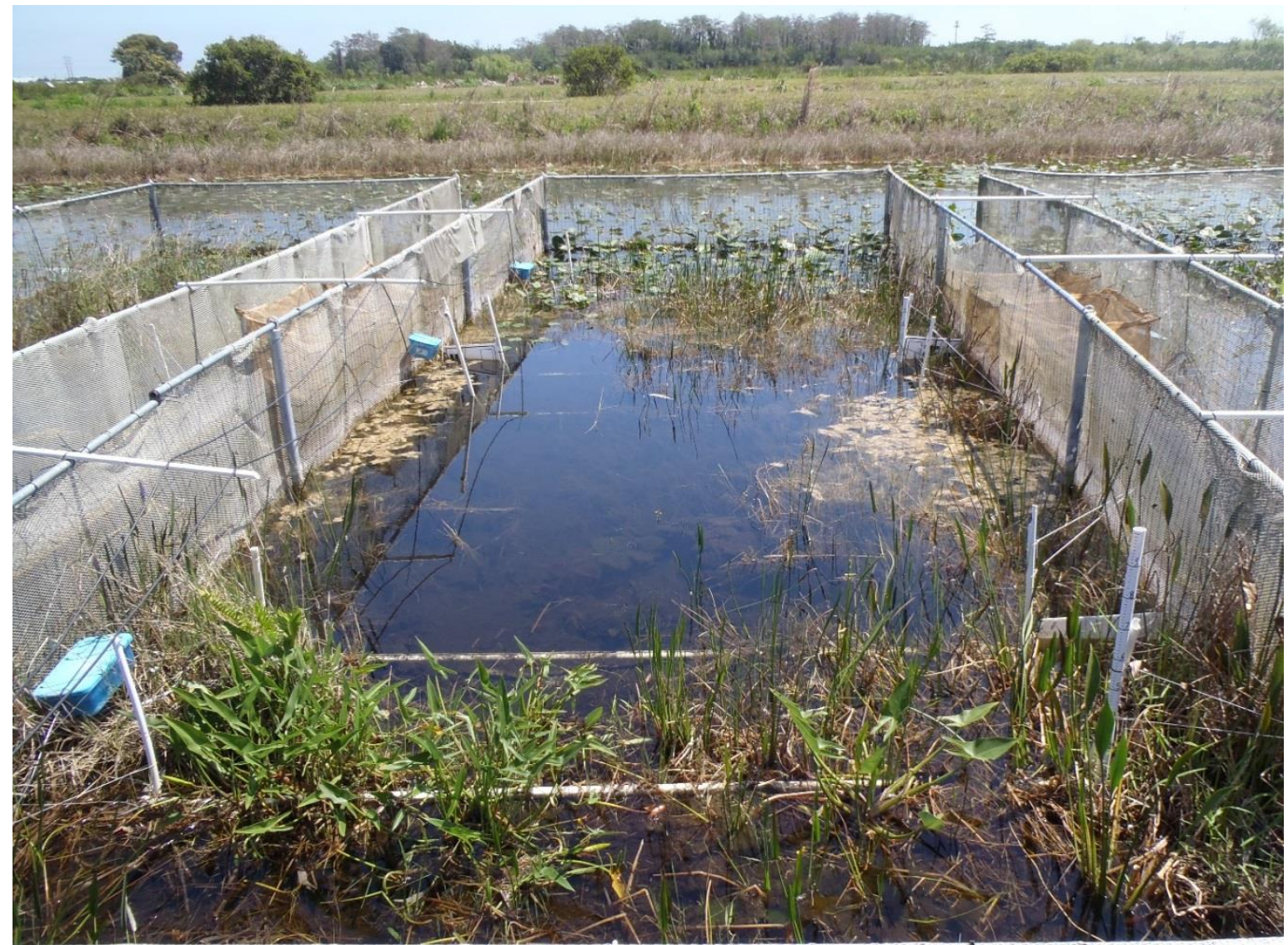

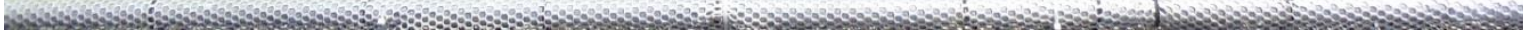

FIGURE 3. Image of one study enclosure. Shows the ridge in the foreground, the open slough in center, and the alligator hole habitat in the background. PVC structures in the enclosures hold antennas.

\section{Fish Detection Data}

We collected data continously over 7 months in the enclosures. A total of 120 spotted sunfish were stocked in enclosures over the 217 day period of data collection (January 12- August 17, 2015), with an average total density of 18 fish per day in the 6 enclosures (3-6 fish per enclosure). Fish were continously replaced over this period if their densities became low. Data on the movements and distribution of spotted sunfish across the 3 habitats were recorded by all 6 enclosures, 6 readers, and 18 antennas until April 24, after which 3 enclosures systems went offline. Fish averaged $9.6 \mathrm{~cm}$ in 
standard length (range: 8.0 to $14.4 \mathrm{~cm}$ ) and $37.5 \mathrm{~g}$ (range: $17-117 \mathrm{~g}$ ) in weight at stocking and were present for an average of 37 days (range $=1$ to 184 days). A total of 37 fish had data collection periods greater than 50 days, and these fish provided the bulk of the detection data. I captured Spotted Sunfish by hook and line in macrocosm 1 at LILA. All fish were weighed, measured, photographed and PIT tagged before stocking into enclosures. Data recorded by readers came in the form of a tag number, the corresponding antenna where the tag was detected (antenna 1=ridge, 2=slough, 3=alligator hole, e.g., FIGURE 5), and a time/date stamp. Since tag detections are sequential and continuous in time and space (fish are detected continously by multiple antennas as they move among habitats), they provide a complete record of an individual's distribution across the 3 marsh habitats that could be related to hydrological parameters (FIGURE 5).

In all analyses, I used day as a key unit of replication, allowing me to test for the effects of daily hydrological conditions on fish behavior. Detections were also averaged for all fish detected on a daily time step in order to obtain a more robust measure of fish behavior (Rehage et al. 2015). Analyses focused on two key response variables: the proportion of detections across habitats and fish activity level. I calculated proportion of detections by dividing the number of detections in a given habitat by the total number of detections recorded for a given day; e.g., the proportion of detections in the ridge for day $\mathrm{i}=\#$ of detections in ridge in day $\mathrm{i} /$ total \# of detections in day $\mathrm{i}$. The same procedure was followed for calculating proportions for the slough and alligator hole. The proportions were then averaged across all fish to obtain a daily average of fish distribution. Activity level was calculated as the daily count (averaged across all fish) of 
movements from one habitat to another. Counts were calculated by summing the total number of different antenna detections (indicative of habitat switches) over the course of 24 hours for each fish, averaging for all fish detected on that day, and repeating the procedure for all days. Since activity is also a relative function of depth and how much space fish have to move in, I adjusted daily activity by the number of habitats flooded (e.g., I divided by 3 if all habitats and by 2 if only slough and alligator hole were flooded).

\section{Hydrological Periods}

The study design expanded 3 key hydrological periods of interest: a) a period of recession during the early dry season, b) a mid-dry season experimental reversal, and c) a period of dry conditions post reversal which included a mild rewetting towards the end of data collection. The reversal period spanned a stretch of 43 days, beginning on 4/13/2015 when water levels were increased rapidly to inundate the previously dry ridge and increase water levels in the slough and alligator hole habitats and ended on 5/25/2015 when water levels returned to pre-reversal conditions (FIGURE 4). Since 2015 was a drought year, the rewetting period at the end of data collection was short and water conditions lower than desired. Water depths were recorded at each weekly data download (33 individual downloads, each lasting an average of 6 days) across the entire

period of data collection. I then built regressions between stage obtained from LILA macrocosm hydrostation (macrocosm 1O, DBHYDRO, https://www.sfwmd.gov/sciencedata/dbhydro) and staff gauges I placed in each enclosure and habitat to calculate continuous water depths in each habitat. 


\section{Prey Sampling}

In order to examine variation in prey conditions relative to hydrologic conditions and test whether prey abundance may drive fish movement among habitats, I sampled for invertebrates across three time periods: the pre-reversal recession and then during the reversal when water levels were both increasing and decreasing (these two were combined for analyses). I used sweeps to sample the ridge and slough using a D-frame net (Turner \& Trexler 1997). Each sweep covered the water column from substrate to surface and extended approximately 1-meter in length. I conducted 1 sweep per enclosure at each sampling event (1 sweep x 6 enclosures x 2 habitats x 3 sampling periods $=36$ samples). Invertebrate samples were preserved in $10 \%$ formalin and brought back to the lab for processing. Samples were then rinsed through a $5 \mathrm{~mm}$ sieve and individual specimens were identified to the class level. All invertebrates were counted to obtain total invertebrate abundance per sample. Only shorter hydroperiod habitats (ridge and slough) were sampled since the high depth of the alligator hole did not allow for proper application of the sampling technique. Drought conditions also prevented us from obtaining a sample during the post-reversal reflooding event. 


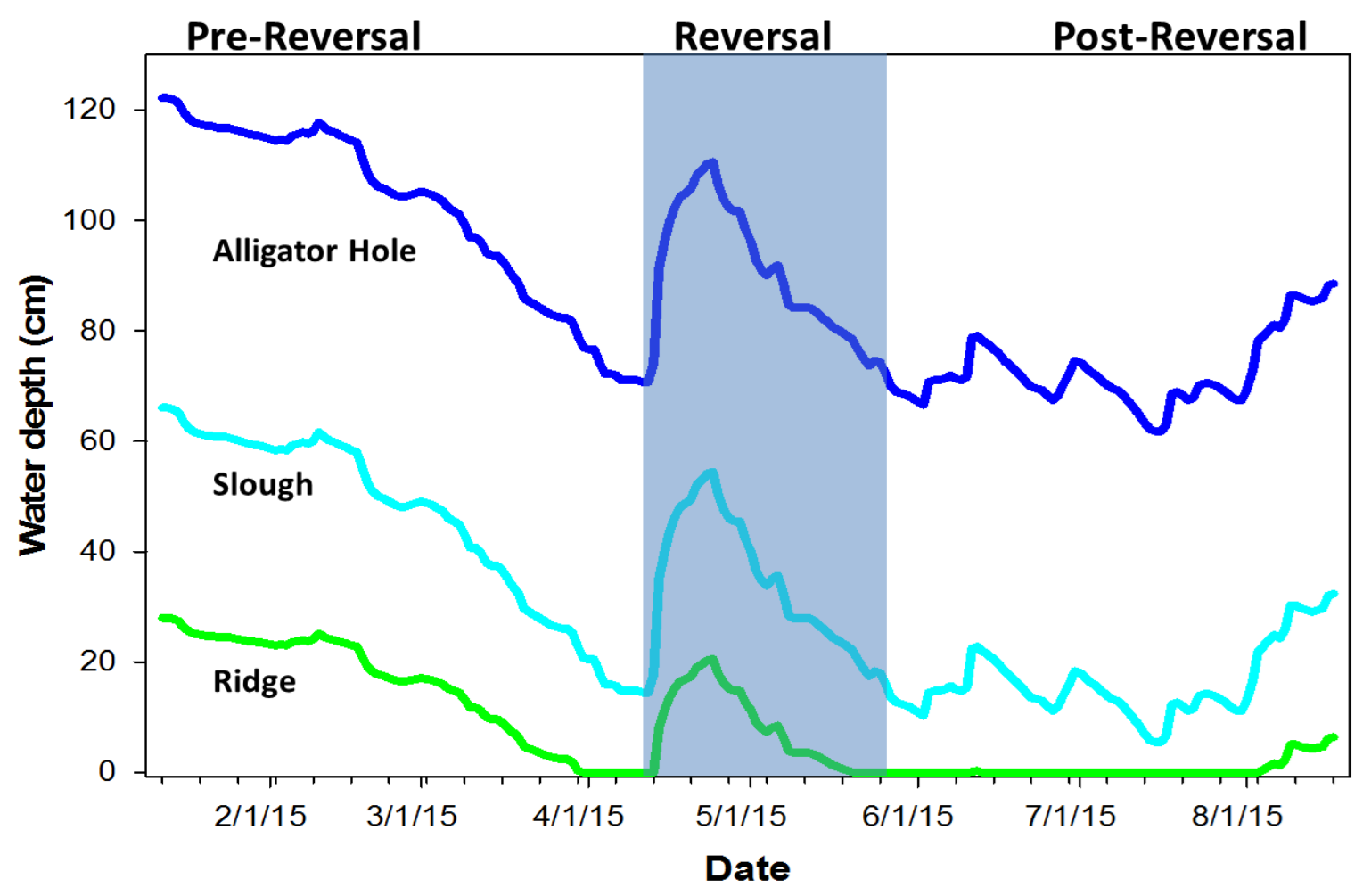

FIGURE 4. Water levels for the 2015 data run across the 3 habitats. See TABLE 2 for additional details on hydrological periods of interest. Blue shading shows the reversal conducted in late April 2015. 

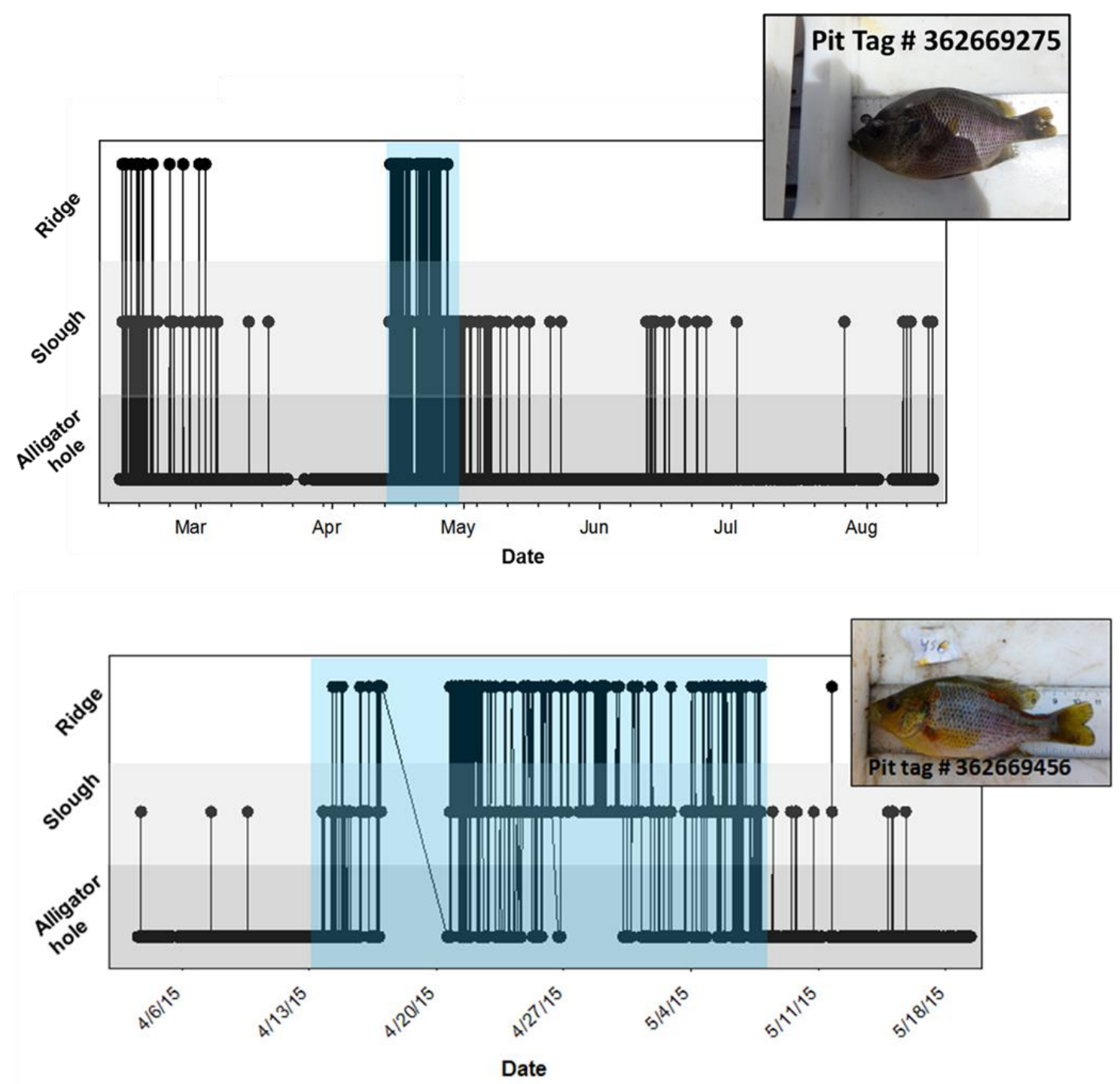

FIGURE 5. Examples of continuous antenna detections for 2 spotted sunfish. Tag \# 9275 across (top) during the entire period of data collection and Tag \# 9456 (bottom) during the reversal (blue shading). Shown are patterns of distribution across the 3 habitats; black circles indicate each tag detections, and lines link sequential detections. Photos of fish were taken at stocking.

\section{Statistical Analyses}

To examine how fish distribution varied over the three time periods of interest (pre-reversal, reversal and post-reversal), I first compared the mean proportion of detections (averaged across all detections days in each time period) using a contingency 
table with a chi-square test. In order to examine variation in fish activity level as a function of hydrological conditions, I used a general linear model approach focusing on three hydrological conditions of interest: 1) increasing vs. decreasing water level days 2) seasonal vs. unseasonal conditions (reversal vs. nonreversal days), and 3) varying daily rates of change in water conditions. For (1) and (2), I ran a mixed model that compared days of increasing and decreasing water, and days of seasonal water change (pre and post reversal combined) vs days of unseasonal water change (during the reversal) with the appropriate interactions.

For (3) I used a general linear model that tested for the effect of the rate of water level change on activity. Here, I calculated the total depth change (in $\mathrm{cm}$ ) from one day to the next and binned days into categories of depth change that incorpated direction and speed of change from neutral (no change) to extreme high rates of change. I determined these bins by a) examining data from mulitple years of hydrological data and the distribution of water level change, and by b) from previous studies on water level changes (Herring et al 2010, Gawlik 2002). I used 3 Everglades hydrological sites (WTA 9, 63, and P33) and examined changes in water levels across years of varying hydrological conditions: 2009 a year of marked changes in water levels, 2010 a wet year, and 2011 a drought year (FIGURE 6). Wading bird studies such as Gawlik (2002) reported an average Everglades dry season recession rate of $0.5 \mathrm{~cm} /$ day, while Herring et al (2010) observed interannual variability of slow $(0.15-.34 \mathrm{~cm} /$ day $)$ to fast $(>1.6 \mathrm{~cm} /$ day $)$ recession rates. Based on these field recession rates, I selected 3 bin rates to represent low to average rates $(0.01$ to $1.49 \mathrm{~cm} /$ day $)$, high $(1.5-2.5 \mathrm{~cm} /$ day $)$ and very high or extreme $(>2.5 \mathrm{~cm} /$ day) rates of change. 
Last I compared invertebrate abundances across habitats and sampling periods and the interacition with another general linear model. A quasipoisson regression with a $\log$ link function was used for all models to account for overdispersion common in ecological count data (Ver Hoef \& Boveng 2007). I used a liklihood ratio test in each model and Tukey post-hoc tests for multiple comparisons. I also ran an analysis of deviance to select for the most parsimonius model and assessed model fit using McFadden's deviance based pseudo R2 measure, commonly applied to fish count data and unaffected by overdispersion (Mittlböck \& Heinzl 2004, Mather et al. 2008). All statistical analyses were performed using R-Studio.
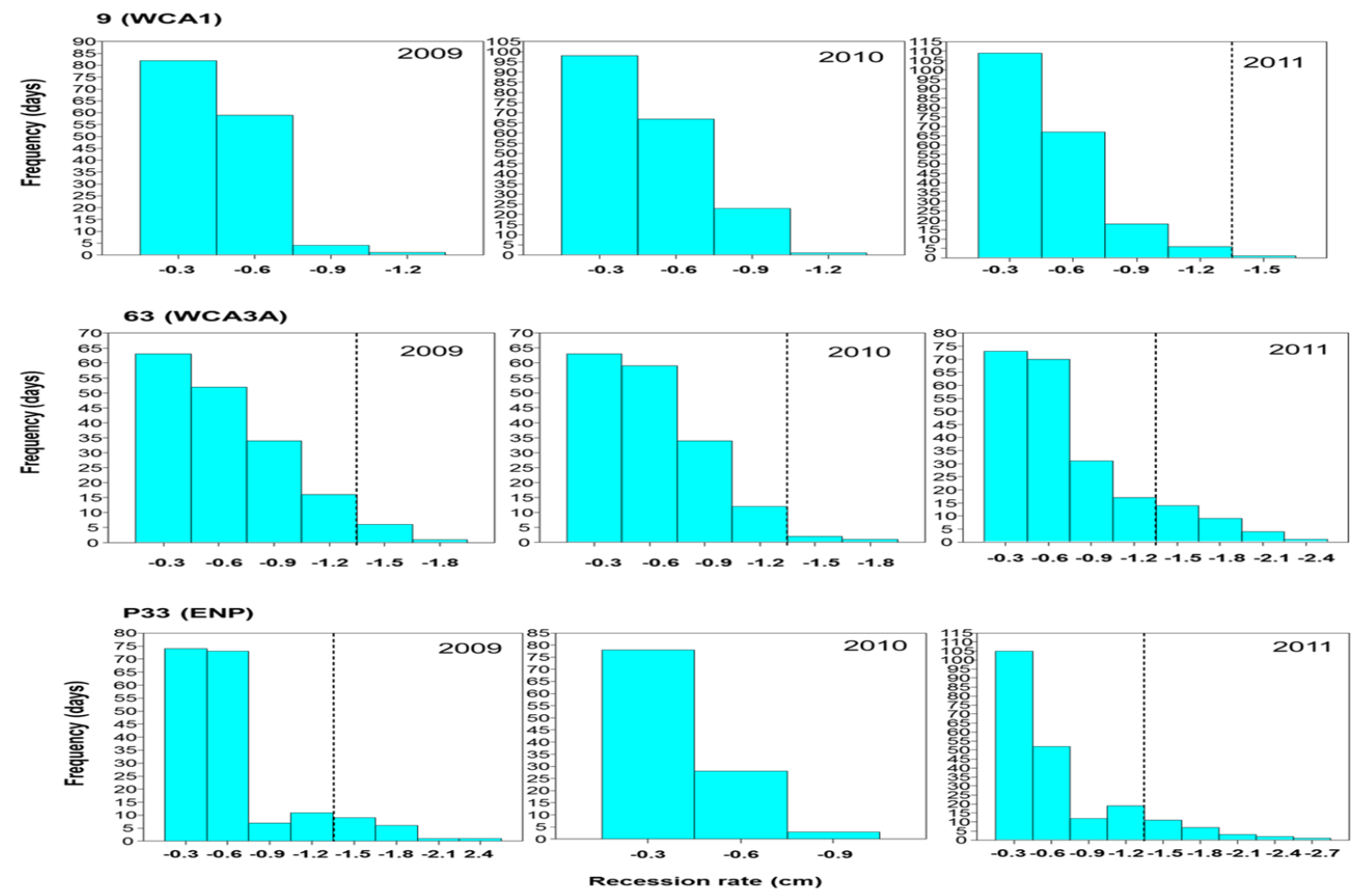

FIGURE 6. Frequency of recession rates across 3 hydrostations. (WCA1-9, WCA3-63 and Everglades National Park P33) in $\mathrm{cm}$ for 2009 (strong recession), 2010 (wet year) and 2011 (drought year). Dashed line indicates rates above $1.5 \mathrm{~cm}$. 
TABLE 1. Summary of water conditions in 2015 over the three hydrological periods of interest (see FIGURE 5 for continuous water levels). Shown are dates, average water depths, and ranges in depth over each period: pre-reversal drying, experimental reversal, post-reversal drying and rewettting.

\begin{tabular}{|c|c|c|c|c|c|}
\hline \multirow{2}{*}{$\begin{array}{l}\text { Hydrological } \\
\text { periods }\end{array}$} & \multicolumn{5}{|c|}{ Water levels (cm) } \\
\hline & Dates & \# of days & Ridge & Slough & Alligator hole \\
\hline \multirow[t]{2}{*}{ PRE-REVERSAL } & $1 / 12 / 15-4 / 12 / 15$ & 91 & 15.0 & 45 & 101.2 \\
\hline & & & $(0-28.0)$ & $(14-66.1)$ & $(70.8-122.2)$ \\
\hline \multirow{2}{*}{$\begin{array}{l}\text { EXPERIMENTAL } \\
\text { REVERSAL }\end{array}$} & $4 / 13 / 15-5 / 25 / 15$ & 43 & 8.3 & 34.8 & 91 \\
\hline & & & $(0-20.5)$ & $(17.7-45.5)$ & $(74.1-101.7)$ \\
\hline \multirow{2}{*}{$\begin{array}{l}\text { POST- } \\
\text { RESERVAL }\end{array}$} & $5 / 26 / 15-7 / 31 / 15$ & 66 & 1.1 & 17.7 & 73.9 \\
\hline & & & $(0-20.5)$ & $(17.7-45.5)$ & $(74.1-101.7)$ \\
\hline & & & 8.1 & 31.9 & 88.2 \\
\hline $\begin{array}{l}\text { Total period of } \\
\text { data collection }\end{array}$ & $1 / 12 / 15-8 / 17 / 15$ & 217 & $(0-28.0)$ & $(5.5-66.1)$ & $(61.8-122.2)$ \\
\hline
\end{tabular}

\section{RESULTS}

\section{Variation in Fish Habitat Use}

Habitat selection by spotted sunfish was dominated by use of the deeper habitats in the enclosures. Across the length of the study, $78.7 \%$ of antenna detections were in the alligator hole, relative to $15.9 \%$ in the slough and $5.3 \%$ in the ridge. This habitat distribution varied, however, as a function of the experimental reversal (Chi-square test, p-value $=0.02$ ). With the rapid increase in water levels of the reversal, spotted sunfish decreased use of the alligator hole and increased use of the newly re-flooded ridge (FIGURE 7). Mean antenna detections in the alligator hole decreased from $81 \%$ to $71 \%$ 
from recession to reversal, and increased from $0 \%$ to $13 \%$ in the ridge. Post reversal, use of the ridge decreased back to $2 \%$ of antenna detections.

Within each hydrological period, changes in daily behavior were also observed (FIGURE 8). Fish use of the ridge habitat dropped steadily during the early drying period before peaking during the experimental reversal. Slough use increased moderately during the early stages of the pre-reversal drying period until a short but fast drop in water level was followed by a $>30 \%$ decrease in detections (FIGURE 8). Slough use then rose rapidly at the onset of the experimental reversal and then declined as water levels began to recede. During the prolonged post-reversal drying period, fish responded to small increases in water level with rapid increases in slough use. Peak slough usage occurred during the final rewetting period (FIGURE 8). Fish use of the alligator hole was highest at the lowest water levels but decreased rapidly as fish moved to shallower habitats in response to increases in depth during the reversal and post reversal periods.

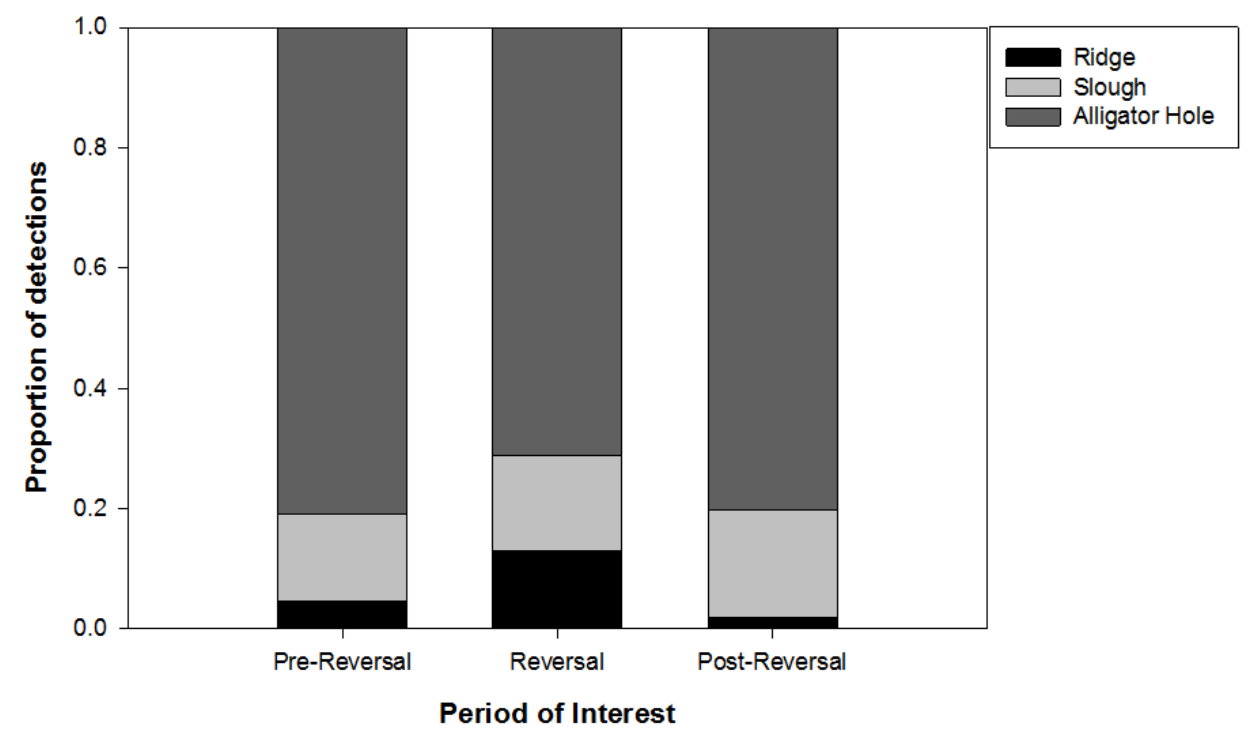

FIGURE 7. Habitat use by period of interest across the 3 habitats. Shown is the mean proportion of detections across each hydrological period. 


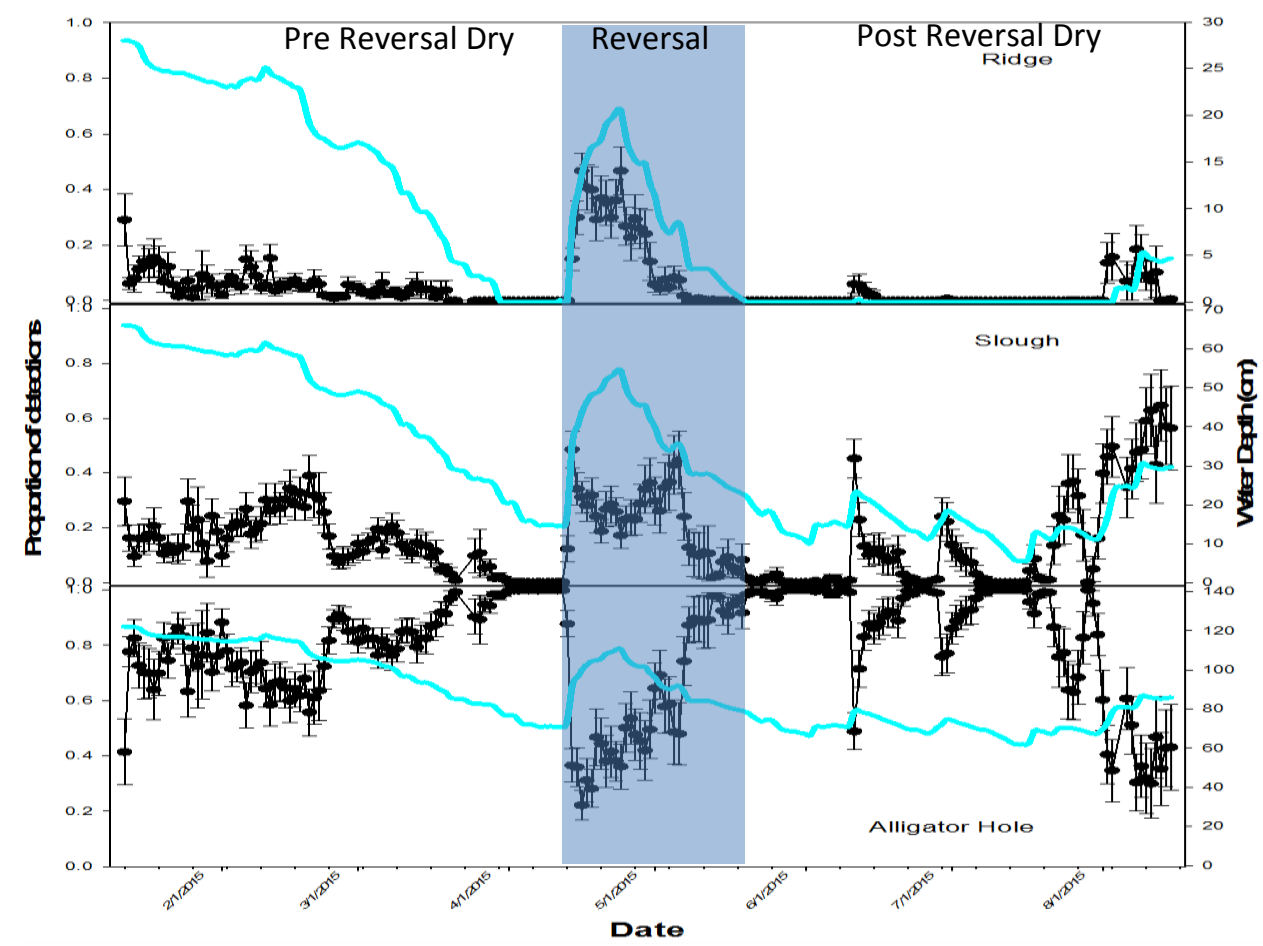

FIGURE 8. Daily proportions of antenna detections for the 3 habitats (ridge, slough and alligator hole) averaged across all fish. Shown for the entire period of data collection, January to August 2015 (shown are means \pm SEs). Blue lines show water level in each habitat, including the experimental reversal in late April.

\section{Fish Activity as a Function of Hydrologic Period and Direction}

Fish activity differed as a function of hydrologic period, direction, and the interaction (TABLE 2) Daily movements were more than twice as high during the experimental reversal than during periods of seasonal change. Similarly, fish were twice as active during increasing water levels vs during decreasing water levels (FIGURE 9). Fish activity peaked at increasing water levels during the reversal, being more than 3 times as high relative to receding water levels during the reversal period and both the increasing and decreasing seasonal changes in water level (FIGURE 10). 


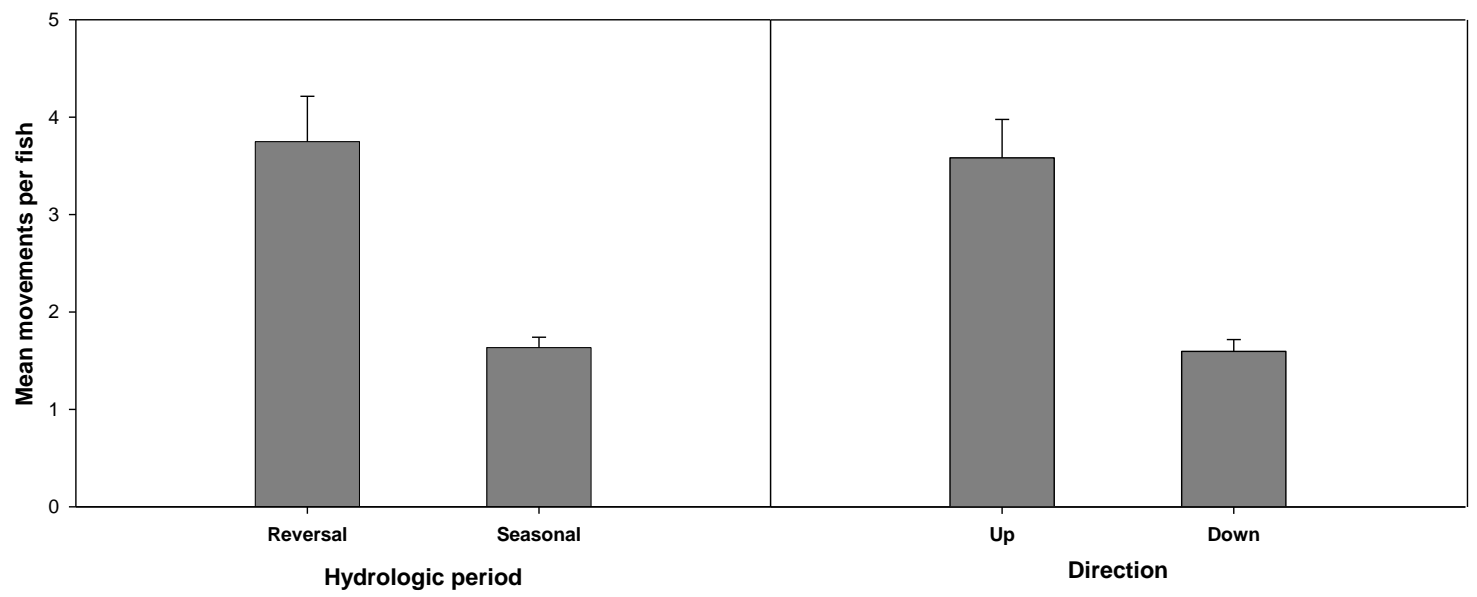

FIGURE 9. Activity level of spotted sunfish by hydrologic direction \& period. Shown are response to the experimental reversal and seasonal changes in water level (left) as well as activity level relative to the direction of depth change (right).

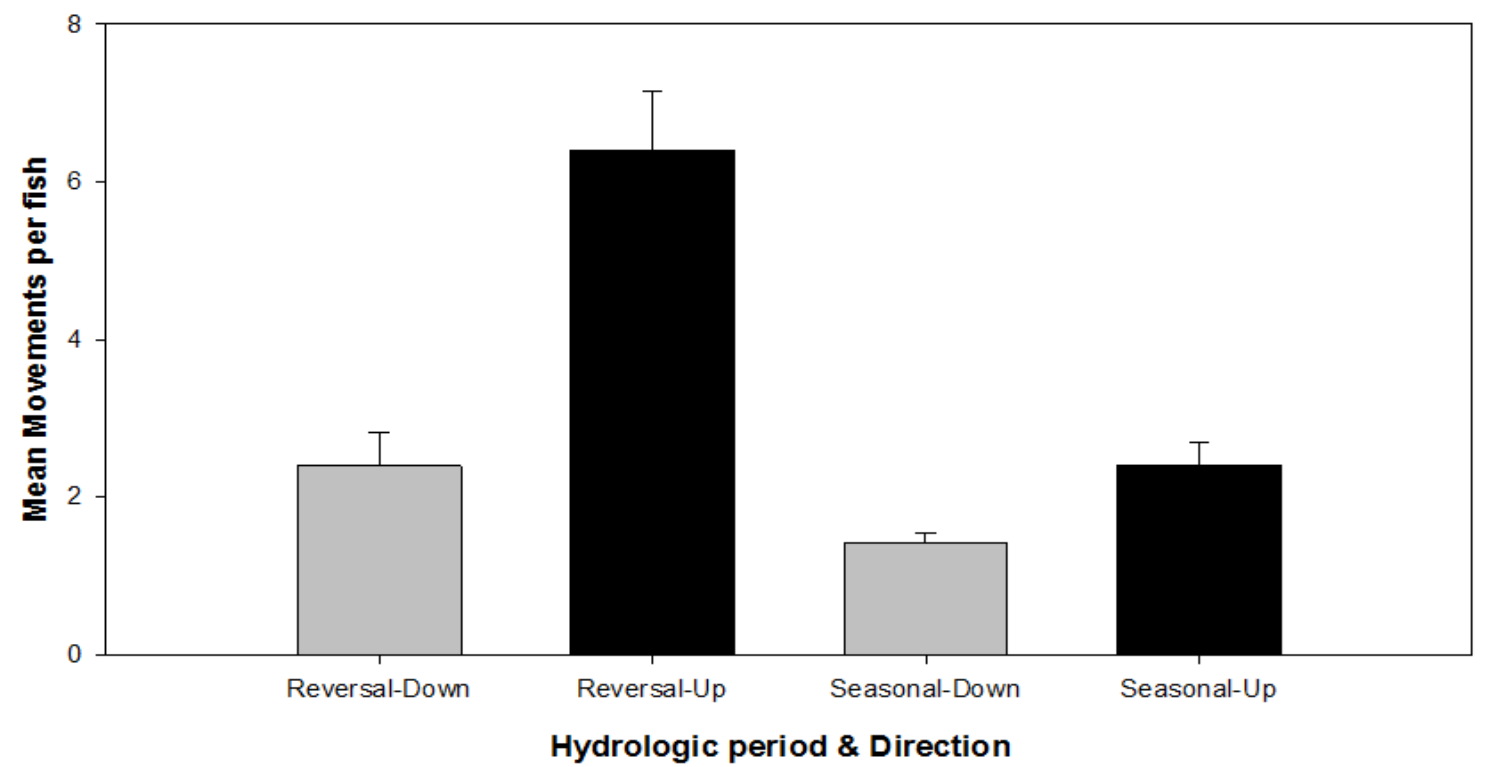

FIGURE 10. Activity level of spotted sunfish in response to the interaction of season and direction of depth change. Shown are means of daily movements across all fish tracked and all days of data collection. Shown are means \pm SE. 
Fish Activity in Response to Variation in Rate

Spotted sunfish also exhibited marked differences in activity relative to varying rates of depth change (FIGURE 11). Activity was consistently higher as water levels increased, on average 3 times higher relative to when water levels were steady ( $\mathrm{p}<$ 0.001). In contrast, during decreasing water levels activity increased only at the highest rates of recession $(2.5+\mathrm{cm} /$ day $)$. Here, fish activity was more than twice as high as steady water levels and moderate and fast recession rates. Fish activity was similar between the no change and the moderate and fast recession rate ( $p>0.99)$.

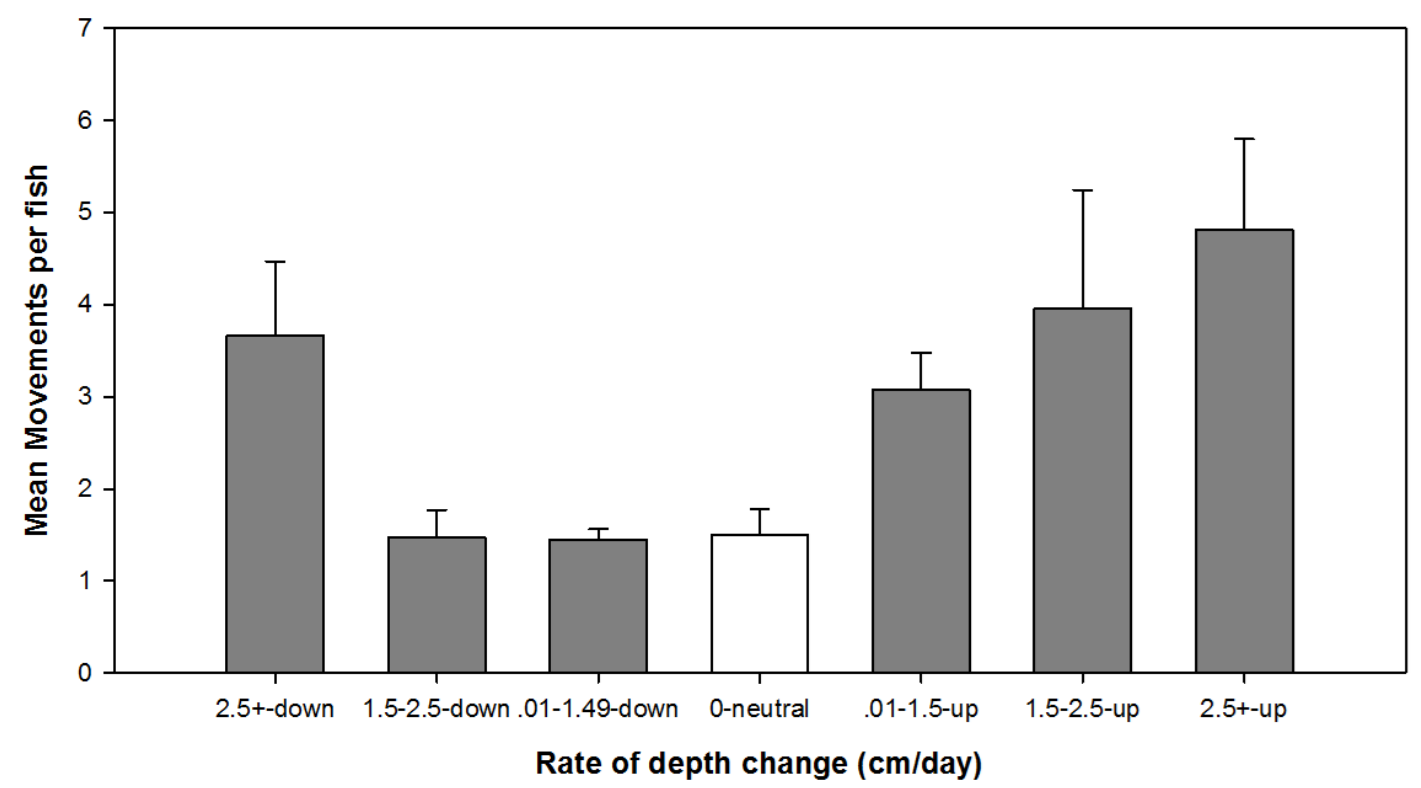

FIGURE 11. Activity level as a function of daily rate of change in water depth. Rates of change were classified into $1.5 \mathrm{~cm}$ /day increasing and decreasing bins relative to days with no change (neutral). 
Invertebrate Abundance Relative to Sampling Period and Habitat

Invertebrate abundance differed as a function of sampling period but not across habitats (TABLE $2 \&$ 3). These invertebrate communities were dominated by gastropods, bivalves, crustaceans, and insects. The most abundant specimens collected were amphipods, freshwater shrimp, and snails. The average number of specimens collected per sweep was highest during the pre-reversal drying period and lowest during the reversal (FIGURE 12).

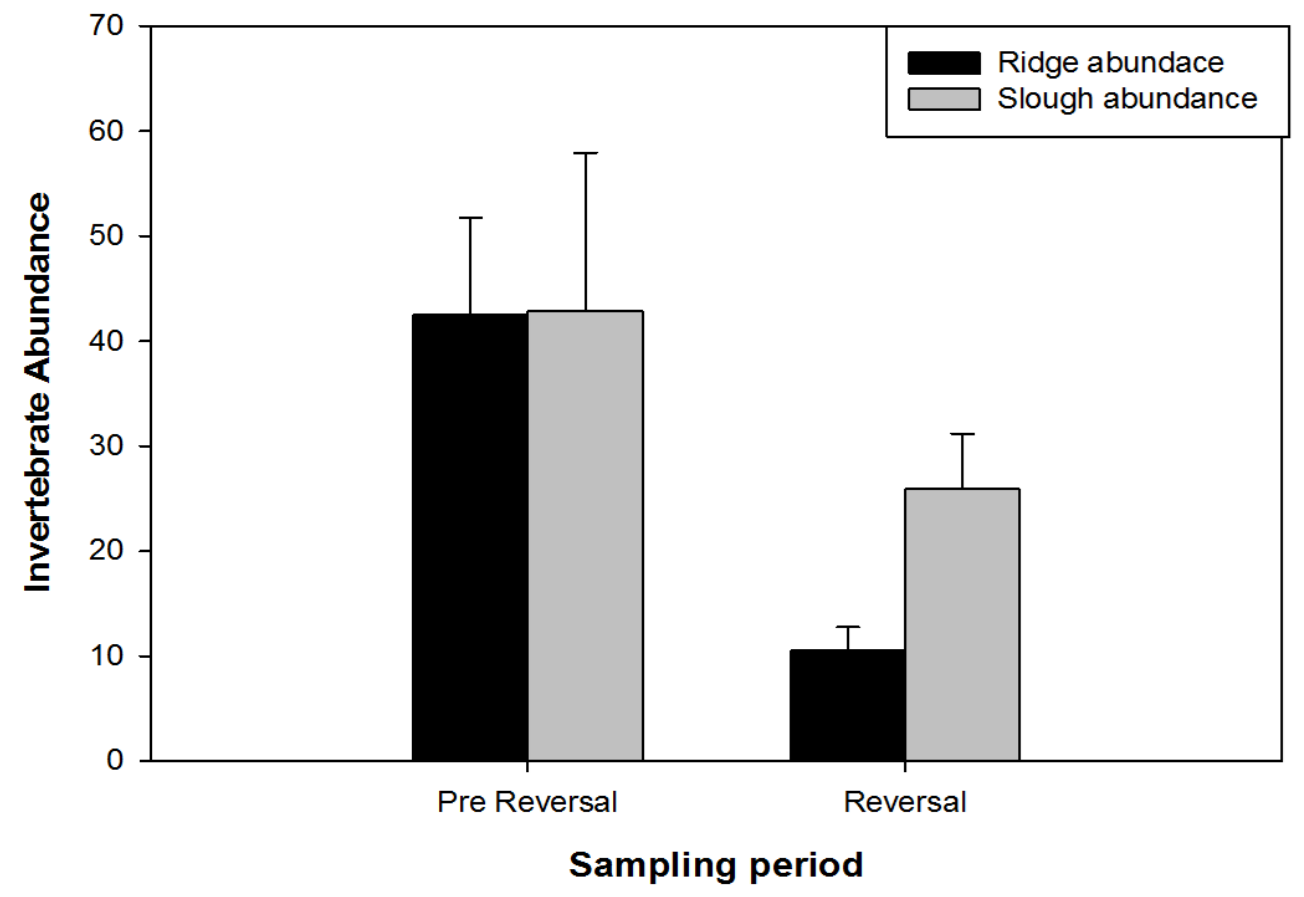

FIGURE 12. Invertebrate abundance across sampling period and habitat. Abundance quantified as the average number of specimens (mollusks, arthropods, $\&$ annelids) collected per enclosure. 
TABLE 2: Analysis of Variance for fish activity as a function of hydrologic period and direction of depth change (model 1), variation in rate of depth change (model 2), and invertebrate abundance as a function of hydrologic period and habitat (model 3). Degrees of Freedom with residuals (DF), F-Value, Significance level (P-value) and assessed model fit (McFadden's $\mathrm{R}^{2}$.) reported.

\begin{tabular}{|c|c|c|c|c|}
\hline Variable & DF & F-Value & P-value & McFadden's $\mathbf{R}^{2}$. \\
\hline \multicolumn{5}{|c|}{ Model 1} \\
\hline Hydrologic Period & 1,182 & 60.75 & $<.001$ & \multirow{3}{*}{0.336} \\
\hline Direction & 1,182 & 42.79 & $<.001$ & \\
\hline Hydrologic Period*Direction & 1,182 & 24.15 & $<.001$ & \\
\hline \multicolumn{5}{|c|}{ Model 2} \\
\hline Rateclass & 6,204 & 12.04 & $<.001$ & 0.249 \\
\hline \multicolumn{5}{|c|}{ Model 3} \\
\hline Hydrologic Period & 1,30 & 11.7 & 0.002 & \multirow{3}{*}{0.384} \\
\hline Habitat & 1,30 & 2.048 & 0.163 & \\
\hline Hydrologic period*Habitat & 1,30 & 1.053 & 0.313 & \\
\hline
\end{tabular}

\section{DISCUSSION}

Movement is one of the major ways in which animals respond to changing environmental conditions and key to understanding how ecosystems function (Dingle \& Drake 2007, Kays et al 2015, Patterson et al. 2007). Changes in hydrologic regimes are of particular importance to aquatic ecosystems, having a strong influence on the ecology of fishes, including their distributional patterns (Mcfarland 2015, L. Roy et al. 2013, Roberts et al. 2016). In my study, I tracked the movement and distribution patterns of Everglades fishes in response to seasonal variations in water level. The timing, direction, rate of change in water levels, and availability of invertebrate prey may all influence which habitats fish prefer and how actively they move between them (Rehage et al. 2014, Albanese et al. 2004, Davey \& Kelly 2007). In accordance with my predictions, fish 
were strongly responsive to shifts in timing and direction of hydrologic conditions. In particular, fish were more responsive to increasing water levels vs. decreasing, and to unseasonal vs. seasonal changes in water levels. Fish also were discerning of rates in water level change and whether these rates were at increasing vs. decreasing water levels. Fish consistently showed high rates of movement as water levels increased regardless of rate, but during recession, they show high movements only at the highest rate of recession. Last, aquatic macroinvertebrate abundance was not highest upon first reflooding, and thus likely not a driver of fish movement into shallow habitats.

My study provides a field in situ manipulation of water levels and associated fish behavioral response at large spatiotemporal scales. Examinations of this type of detailed behavioral response in an experimental setting are usually conducted at small scales in lab aquaria and rarely observed in the field. However, recent advances in tracking technology provide an opportunity to observe behavior in the field, while manipulating the drivers of such behavior. Yet, limitations are still present, and in our case we use enclosures to be able to closely track behavioral responses as we manipulated water levels. Our enclosure scale was large (approximately 100 body lengths), but the possibility remains that the enclosure setting may affect fish behavior. However, we suggest that our experimental setting provided a more natural setting in which to quantify fish activity than either tanks or mesocosms studies, where these type of studies are usually conducted (Flecker 1996, Greenberg \& Giller 2000, Winemiller et al. 2006, Power et al. 2008). Detection inhibition from two fish holding in the same detection field at the same time and electrical interferece caused by metal structures also limited the amount area which the antennas detection field could feasibly cover within the enclosures 
(Connolly 2010, Gibbons \& Andrews 2004). I used the flatbed design and a low stocking density to mitigate these problems while still being able to obtain directional movement and a relative measure of habitat use. However, recent technological advances in PIT systems and other animal tracking devices have resolved detection interference problems and provided new approaches to future use in enclosure studies (Hussey et al. 2015, Cooke et al. 2013).

The timing of changes in water level had a significant effect on fish behavior relative to both habitat use and movement activity. In particular, we saw that reflooding caused immediate increases in fish activity not observed with recession. Upon the onset of the experimental reversal, fish rapidly dispersed out of the alligator hole habitat and into the ridge and slough, using these habitats more during this time frame than any other period of data collection. Fish also became very active during the reversal, with the highest amount of movement between habitats occurring during this part of the study. I expected the reversal to illicit a behavioral response in fish and redistribute their abundance across habitats (Rehage et al. 2014) and saw strong support for this hypothesis. The reversal period did not correspond with the expected high invertebrate abundance seen in previous studies of newly inundated floodplain habitats (Jenkins \& Boulton 2003). However, it is difficult to assess the exact impact of foraging behavior on movement in this context as the shallow habitats may require more time to re-populate with macroinvertebrates and newly hatched macroinvertebrates may be difficult to detect and quantify with current sampling techniques. Intraspecific competition for food may also create a dissimilar movement response among individuals (Ward et al. 2006). While we did not detect a high number of aquatic prey, terrestrial prey may have been high. 
Terrestrial invertebrates have been observed to be a chief component of diet samples in other Lepomis species (Weidel 2011) and while not sampled in this study, may provide some incentive for fish to move into newly available habitats. Still, the immediate changes in fish movement and habitat use observed during the reversal and small water depth increases post reversal point to hydrologic regimes as the primary driver behind fish movement. The strong response of fish to water level changes indicates a heightened sensitivity to unseasonal disturbance events (Dorn \& Cook, 2015, Nagrodski et al. 2012).

The directionality of water depth change also influenced fish behavior. Fish were very responsive to increasing water depth, being twice as active when water levels rose as opposed to when they dropped. While responses to stage change and flood pulse by fishes have previously been documented in riverine systems (Albanese et al. 2004, Roy et al 2013, Scruton et al. 2005, Rodger, 2015), the results from this study indicate a similar behavior for fish inhabiting wetland environments. Fish movement into floodplains has often been associated with spawning activity and recruitment, albeit relative to the duration and timing of inundation on floodplain habitats (King et al. 2003, Balcombe \& Arthington 2009, Gorski et al., 2010). For instance, Snedden et al. 1999 observed flood pulse to provide spotted gar with access to crucial spawning and nursery habitat. In my study, I did not observe fish exhibiting spawning behavior as water levels re-inundated the ridge and slough habitats. However, the observed strong response to increasing depth does point to the importance of considering how flooding events may influence the distribution of fish populations across the Everglades landscape.

The rate of change in water depth is another factor which has been known to influence movement patterns in many fish species, particularly in regards to salmonids 
existing in hydrologically altered rivers (Young et al. 2011). I found that fish movement increased during all positive rates of change in water level regardless of the speed at which water levels rose. During days of receding water levels, however, fish were unresponsive in there activity level until the daily average recession rate reached $3+$ $\mathrm{cm} /$ day. At this extreme recession rate, fish movement more than doubled in comparison to slower recession rates and days of no change. Such an increase in activity at rapid rates of recession may be a stranding avoidance response, as previous studies have shown the probability of stranding increases with rate of recession (Davey et al. 2006). Anthropogenic influences have also been documented as the primary cause of fish stranding in freshwater systems (Nagrodski et al. 2012, Young et al. 2011), so the difference in fish response to varying recession rates may again be the product of adapting to a hydrologically altered wetland.

My study builds on previous literature detailing the effects changing hydrologic regimes have on food web dynamics of the Everglades in regards to both economically important fisheries (Boucek \& Rehage 2013, Fedler 2009) and wading birds in particular (Gawlik 2002, Pierce \& Gawlik 2010). Major shifts in fish abundance out of densly concentrated areas and increased movement activity in response to reversal events could create conditions in which bird prey are much harder to locate (Beerens et al. 2011). In particular, the magnitude of a disturbance relative to season can greatly influnece prey distribution (Herring et al, 2010). My findings of strong responses to reflooding events at all rates of reflooding indicate that fish are highly responsive to reflooding and more so relative to recession. My data provides a behavioral mechanism underlying the strong 
effects of reflooding events on prey concentrations observed in the field (Beerens et al. 2011).

Still, there is much more to learn about factors influencing fish behavior as it relates to ecosystem functioning in the Everglades. Differential responses as a function of age and size class of fish could also play a key role in dictating distribution patterns of preffered bird forage, which has shown to be important in previous studies (Kushlan 1979, Kushlan et al. 1975, Schlosser, 1987). Additionally, given that wading birds feed primarily during dawn \& dusk hours (Crozier \& Gawlik 2003, Herring et al. 2010), diel movement patterns of fish in conjunction with seasonal trends are future areas of reseach which may help identify where and when peak foraging opportunities for wading birds occur. It is also important to consider the increasing presence of non-native fishes in the Everglades ecosystem (Rehage et al. 2014, Parkos et al. 2011) as the establishment of introduced fish species may affect the health, behavioral response, and distribution of native fish populations (Gozlan et al. 2010).

\section{CONCLUSIONS}

The findings from my study point to the strong influence changing water levels have on fish and food web dynamics in the Everglades. In particular, fish move and shift habitat more in response to unseasonal disturbance events, increases in water levels relative to receding water levels, and not as a function of aquatic prey abundance. The strong response of fish to reflooding events and potential to alter prey concentration across the Everglades emphasizes the need for climate change awareness and proper 
management of water resources in south Florida. Furthermore, the complex nature of the Everglades pulsed wetland landscape requires additional research on factors influencing fish movements and their relationship to varying hydrologic regimes and food web dynamics. Continued studies are vital in helping natural resource agencies make informed management decisions regarding restoration efforts that will balance human needs with healthy ecosystem functioning. 


\section{WORKS CITED}

Adams, A. J., Wolfe, R. K., Pine, W. E., \& Thornton, B. L. (2006). Efficacy of PIT tags and an autonomous antenna system to study the juvenile life stage of an estuarinedependent fish. Estuaries \& Coasts, 311-317.

Albanese, B., Angermeier, P. L., \& Dorai-Raj, S. (2004). Ecological correlates of fish movement in a network of Virginia streams. Canadian Journal of Fisheries and Aquatic Science, 857-869.

Balcombe, S. R., \& Arthington, A. H. (2009). Temporal changes in fish abundance in response to hydrological variability in a dryland floodplain river. Marine and Freshwater Research, 146-159.

Balcombe, S., Bunn, S., McKenzie-Smith, F., \& Davies, P. (2005). Variability of fish diets between dry and flood periods in an arid zone floodplain river. Journal of Fish Biology, 1552-1567.

Beerens, J. M., Gawlik, D. E., Herring, G., \& Cook, M. I. (2011). Dynamic habitat selection by two wading bird species with divergent foraging strategies in a seasonally fluctuating wetland. The Auk, 651-662.

Birkett, P., Vanak, A., Muggeo, V., Ferreira, S., \& R, S. (2012). Animal perception of seasonal thresholds: Changes in elephant movement in relation to rainfall patterns. PLoS ONE, 38363.

Boucek, R. E., \& Rehage, J. (2013). No free lunch: displaced marsh consumers regulate a prey subsidy to an estuarine consumer. Oikos, 1453-1464

Boucek, R. E., Soula, M., Tamayo, F., \& Rehage, J. S. (2016). A once in 10 year drought alters the magnitude and quality of a floodplain prey subsidy to coastal river fishes. Canadian Journal of Fisheries and Aquatic Sciences, 1672-1678.

Brandt, L., Campbell, M. R., \& Mazzotti, F. J. (2010). Spatial distribution of alligator holes in the central Everglades. Southeastern Naturalist, 487-496.

Bunn, S. E., \& Arthington, A. H. (2002). Basic principles and ecological consequences of altered flow regimes for aquatic biodiversity. Environmental Management, 492507. 
Chick, J. H., Ruetz III, C. R., \& Trexler, J. C. (2004). Spatial scale and abundance patterns of large fish communities in freshwater marshes of the Florida Everglades. Wetlands, 652-664.

Connolly. (2010). Guidelines to Indirectly Measure and Enhance Detection Efficiency of Stationary PIT Tag Interrogation Systems in Streams. Pacific Northwest Aquatic Monitoring Partnership Special Publication, 119-125.

Cooke, S. J., Midwood, J. D., Thiem, J. D., Klimley, P., Lucas, M. C., Thorstad, E. C., . . . Ebner, B. C. (2013). Tracking animals in freshwater with electronic tags: past, present and future. Animal Biotelemetry, 1-19.

Crozier, G. E., \& Gawlik, D. E. (2003). Wading bird nesting effort as an index to wetland ecosystem integrity. Waterbirds, 303-324.

Cucherousset, J., Paillisson, J.-M., Carpentier, A., \& Chapman, L. J. (2007). Fish emigration from temporary wetlands during drought: the role of physiological tolerance. Fundamental and Applied Limnology, 169-178.

Davey, A., Kelly, D., \& Biggs, B. (2006). Refuge-use strategies of stream fishes in response to extreme low flows. Journal of Fish Biology, 1047-1059.

Davey, A. J., \& Kelly, D. J. (2007). Fish community responses to drying disturbances in an intermittent stream: a landscape perspective. Freshwater Biology, 1719-1733.

Dewoody, J., Fletcher, D., Mackiewicz, M., Wilkins, S., \& Avise, J. (2000). The genetic mating system of spotted sunfish (Lepomis punctatus): mate numbers and the influence of male reproductive parasites. Molecular Ecology, 2119-2128.

Dingle, H., \& Drake, V. A. (2007). What is migration? Oxford Journals, 113-121.

Dorn, N. J., \& Cook, M. I. (2015). Hydrological disturbance diminishes predator control in wetlands. Ecology, 2984-2993.

Dudgeon, D. (2000). Large-scale hydrological changes in tropical Asia: Prospects for riverine biodiversity. BioScience, 793-806.

Fedler, T. (2009). The Economic impact of recreational fishing in the Everglades region. The Everglades Foundation, 1-17.

Flecker, AS (1996) Ecosystem engineering by a dominant detritivore in a diverse tropical stream. Ecology 77:1845-1854. 
Frederick, P., Gawlik, D., Ogden, J., Cook, M., \& Lusk, M. (2009). The White ibis and wood stork as indicators of restoration of the Everglades ecosystem. Ecological Indicators, 83-95.

Garcia, A. M., Vieira, J. P., Winemiller, K. O., Moraes, L. E., \& Paes, E. T. (2012). Factoring scales of spatial and temporal variation in fish abundance in a subtropical estuary. Marine Ecology, 121-135.

Gasith, A., \& Resh, V. H. (1999). Streams in Mediterranean Climate Regions: Abiotic Influences and Biotic Responses to Predictable Seasonal Events. Ecology, Evolution, and Systematics, 51-81.

Gawlik, D. E. (2002). The effects of prey availability on numerical response of wading birds. Ecological Monographs, 329-346.

Gawlik DE, Botson B (2008) Aquatic fauna seasonal concentrations. Deliverable 17: 2007. Annual report submitted to the South Florida Water Management District.

Gibbons, J. W. (2003). Terrestrial habitat: A vital component for herptofauna of isolated wetlands. Wetlands, 630-635.

Gibbons, J. W., \& Andrews, K. M. (2004). PIT tagging: A Simple Technology at Its Best. BioScience, 447-454.

Gorski, K., Winter, H., Dee leeuw, J., Minin, A., \& Nagelkerke, L. (2010). Fish spawning in a large temperate floodplain: the role of flooding and temperature. Freshwater Biology, 1509-1519.

Gozlan, R., Britton, J., Cowx, I., \& Copp, G. (2010). Current Knowledge on non-native fishwater fish introductions. Journal of fish biology, 751-786.

Harding Gradil, K. J. (2015). Thermal performance covaries with environmental temperature across populations of Atlantic salmon (Salmo salar). Doctoral dissertation, University of Western Ontario.

Herbert, M. E., \& Gelwick, F. P. (2003). Spatial variation of headwater fish assemblages explained by hydrologic variability and upstream effects of impoundment. Copeia, 273-284.

Herring, G., Gawlik, D. E., Cook, M. I., \& Beerens, J. M. (2010). Sensitivity of nesting great egrets (Ardea alba) and white ibises (Eudocimus albus) to reduced prey availability. The Auk, 660-670. 
Hohausova, E., Copp, G., \& Jankovsky, P. (2003). Movement of fish between a river and its backwater: diel activity and relation to environmental gradients. Ecology of Freshwater Fish, 107-117.

Hohausová, E., Lavoy, R. J., \& Allen, M. S. (2010). Fish dispersal in a seasonal wetland: influence of anthropogenic structures. Marine \& Freshwater Research, 682-694.

Hussey, N. E., Kessel, S. T., Aarestrup, K., Cooke, S. J., Cowley, P. D., Fisk, A. T., . . . Whoriskey, F. G. (2015). Aquatic animal telemetry: A panoramic window into the underwater world. Science, 1221-1233.

Jackson, D. A., Peres-Neto, P. R., \& Olden, J. D. (2001). What controls who is where in freshwater fish communities the roles of biotic, abiotic, and spatial factors. Canadian Journal of Fisheries aquatic science, 157-170.

Jeffres, C. A., Klimley, A. P., Merz, J. E., \& Cech Jr., J. J. (2006). Movement of Sacramento sucker, Catostomus occidentalis, and hitch, Lavinia exilicauda, during a spring release of water from Camanche Dam in the Mokelumne River, California. Environmental Biology of Fishes, 365-373.

Jenkins, K. M., \& Boulton, A. (2003). Connectivity in a dryland river: short-term microinvertebrate recruitment following floodplain inundation. Ecology, 27082723.

Johnson, K., Allen, M., \& Havens, K. (2006). A review of littoral vegetation, fisheries, and wildlife responses to hydrologic variation at Lake Okeechobee. Wetlands, 110-126.

Kays, R., Crofoot, M. C., Jetz, W., \& Wikelski, M. (2015). Terrestrial animal tracldng as an eye on life and planet. Science, 1222-1232.

King, A., Humphries, P., \& Lake, P. (2003). Fish recruitment on floodplains: the roles of patterns of flooding and life history characteristics. Canadian Journal of Fisheries and Aquatic Sciences; , 773-786.

Knorp, N. E., \& Dorn, N. J. (2014). Dissimilar numerical responses of macroinvertebrates to disturbance from drying and predatory sunfish. Freshwater Biology, 1378-1388.

Kobza, R., Trexler, J., Loftus, W., \& Perry, S. (2004). Community structure of fishes inhabiting aquatic refuges in a threatened karst wetland and its implications for ecosystem management. Biological Conservation, 153-165 
Kushlan, J. A. (1979). Feeding ecology and prey selection in the White Ibis. The Condor, 376-379.

Kushlan, J. A., Ogden, J. C., \& Higer, A. L. (1975). Relation of water level and fish availability to wood stork reproduction in the southern Everglades, Florida. U.S. Dept. of the Interior, Geological Survey. 75-434

L. Roy, M., Roy, A. G., Grant, J. W., \& Bergeron, N. E. (2013). Individual variability of wild juvenile Atlantic salmon activity patterns: effect of flow stage, temperature and habitat use. Canadian journal of Fisheries Science, 1082-1091.

Lyon, J., Stuart, I., Ramsey, D., \& O'Mahony, J. (2010). The effect of water level on lateral movements of fish between river and off-channel habitats and implications for management. Marine \& Freshwater Research, 271-278.

Magoulick, D. D., \& Kobza, R. M. (2003). The role of refugia for fishes during drought: a review and synthesis. Freshwater Biology, 1186-1198.

Mather, M. E., Parrish, D. L., Campbell, C. A., McMenemy, J. R., \& Smith, J. M. (2008). Summer temperature variation and implications for juvenile Atlantic salmon. Hydrobiologia, 183-196.

Mcfarland, J. (2015). Trophic pathways supporting Arctic grayling in a small stream on the Arctic Coastal Plain, Alaska. Masters thesis, Unversity of Alaska Fairbanks.

McVoy, C., Park Said, W., Obeysekera, J., VanArman, J. A., Dreschel, \& W., T. (2011). Landscapes and Hydrology of the Predrainage Everglades. South Florida Water Management District.

Mittlböckœ, M., \& Heinzl, H. (2004). Pseudo R-squared measures for generalized linear models. 1st European Workshop on the Assessment of Diagnostic Performance, (pp. 71-80).

Meynecke, JO, Poole GC, Werry J, Lee SY (2008). Use of PIT tag and underwater video recording in assessing estuarine fish movement in a high intertidal mangrove and salt marsh creek. Estuarine, Coastal and Shelf Science 79(1):168-178.

Nagrodski, A., Raby, G. D., Hasler, C. T., Tayor, M. K., \& Cooke, S. J. (2012). Fish stranding in freshwater systems: Sources, consequences, and mitigation. Journal of Environmental Management, 133-141. 
Nathan, R., Getz, W. M., Revilla, E., Holyoak, M., Kadmon, R., Saltz, D., \& Smouse, P. E. (2008). A movement ecology paradigm for unifying organismal movement research. National Academy of Sciences, 19052-19059.

Nielsen, J. L., \& Lisle, T. E. (1994). Thermally stratified pools and their use by steelhead in Northern California Streams. Transactions of the American Fisheries Society, 613-626.

Palmer, M. L., \& Mazzotti, F. J. (2004). Structure of Everglades alligator holes. Wetands, 115-122.

Parkos III, J. J., Ruetz III, C. R., \& Trexler, J. C. (2011). Disturbance regime and limits on benefits of refuge use for fishes in a fluctuating hydroscape. Oikos, 1519-1530.

Patterson, T. A., Thomas, L., Wilcox, C., Ovaskainen, O., \& Matthiopoulos, J. (2007). State-space models of individual animal movement. Trends in Ecology and Evolution, 87-94.

Pierce, R. L., \& Gawlik, D. E. (2010). Wading bird foraging habitat selection in the Florida Everglades. Waterbirds, 494-503.

Power ME, Parker MS, Dietrich WE (2008) Seasonal reassembly of a river food web: floods, droughts, and impacts of fish. Ecological Monographs 78:263-282.

Rehage, J. S., Boucek, R. E., Cline, E. A., Cook, M., Kobza, R., \& Saha, A. (2014). Turning passive detection systems into field experiments: An application using wetland fishes and enclosures to track fine-scale movement and habitat choice. ethologica, 53-61.

Rehage, J. S., Cook, M. I., \& Hill, G. J. (2015). Responsiveness of fish to seasonal and short term variation in hydrological conditions. Final report to South Florida Water Management District. West Palm Beach, Fl.

Rehage, J., \& Trexler, J. C. (2006). Assessing the net effect of anthropogenic disturbance on aquatic communities in wetlands: community structure relative to distance from canals. Hydrobiologia, 359-373.

Roberts, J. H., Anderson, G. B., \& Angermeier, P. L. (2016). A Long-Term Study of Ecological Impacts of River Channelization on the Population of an Endangered Fish: Lessons Learned for Assessment and Restoration. Water, 1-38.

Rodger, A. W. (2015). Hydrology and larval fish dynamics in Texas rivers: Science to evaluate environmental flow standards. Master's thesis, Texas A\&M University 
Roman, J., Estes, J. A., Morissette, L., Smith, C., Costa, D., McCarthy, J., . . Smetacek, V. (2014). Whales as Marine Ecosystem Engineers. Frontiers in Ecology and the Environment, 377-385.

Rubenstein, D. R., \& Hobson, K. A. (2004). From birds to butterflies: animal movement patterns and stable isotopes. Trends in Ecology and Evolution, 256-263.

Schlosser, I. J. (1987). The role of predation in age and size related habitat use by stream fishes. Ecology, 651-659.

Scruton, D., Pennell, D., Robertson, M., Ollerhead, L., Clarke, K., Alfredsen, K., . . . McKinley, R. (2005). Seasonal response of juvenile Atlantic Salmon to experimental hydropeaking power generation in newfoundland, Canada. North American Journal of Fisheries Management, 964-974.

Skov, C., Brodersen, J., Bronmark, C., L.-A., H., Hertonsson, P., \& Nilsson, P. (2005). Evaluation of PIT-tagging in cyprinids. Journal of Fish Biology, 1195-1201.

Snedden, G. A., Kelso, W. E., \& Rutherford, D. A. (1999). Diel and seasonal patterns of spotted gar movement and habitat use in the lower Atchafalaya River Basin, Louisiana. Transactions of the American Fisheries Society, vol. 128, 144-154.

Turner, A. M., \& Trexler, J. C. (1997). Sampling aquatic Invertebrates from marshes: evaluating the options. Journal of the North American Benthological Society, 694709.

Ver Hoef, J. M., \& Boveng, P. L. (2007). Quasi-poisson vs. negative binomial regression: How should we model overdispersed count data? Publications, Agencies and Staff of the U.S. Department of Commerce, 2766-2772.

Ward, A. J., Webster, M. M., \& Hart, P. J. (2006). Intraspecific food competition in fishes. Fish and Fisheries, 231-261.

Webb, J. K., Pringle, R. M., \& Shine, R. (2004). How do nocturnal snakes select diurnal retreat sites? Copeia, 919-925.

Weidel, B. C., Carpenter, S. R., Kitchell, J. F., \& Vander Zanden, M. J. (2011). Rates and components of carbon turnover in fish muscle: insights from bioenergetics models and a whole-lake 13C addition. Canadian Journal of Fisheries and Aquatic Sciences, 387-399.

Winemiller KO, Montoya JV, Roelke DL, Layman CA, Cotner JB (2006) Seasonally varying impact of detritivorous fishes on the benthic ecology of a tropical 
floodplain river. Journal of the North American Benthological Society 25:250-262.

Young, Paciencia S., Cech Jr., Joseph J., \& Thompson, Lisa C. (2011). Hydropowerrelated pulsed-flow impacts on stream fishes: A brief review, conceptual model, knowledge gaps, and research needs. Reviews in Fish Biology and Fisheries, 713-731.

Zeman, S. M. (2015). Orientation behavior and feeding ecology of the Scyphomedusa chrysaora fuscescens. Masters Thesis, University of Oregon.

Zeug, S. C., \& Winemiller, K. O. (2007). Ecological correlates of fish reproductive activity in floodplain rivers: a life-history-based approach. Canadian Journal of Fisheries and Aquatic Sciences, 1291-1301. 